\title{
São Paulo Antigo, uma encomenda da modernidade: as fotografias de Militão nas pinturas do Museu Paulista*
}

\author{
Solange Ferraz de Lima \\ vânia Carneiro de Carvalho \\ MP/Universidade de São Paulo.
}

Ao assumir a direção do Museu Paulista, em 1917, Affonso de Escragnole Taunay dedica-se a estruturar a Seção de História Nacional e a desenvolver um projeto de exposições históricas visando as comemorações do centenário da Independência em 1922. Das dezesseis salas de exposição, quatro são reservadas à história de São Paulo, das quais duas voltadas especificamente à "reconstituição" da cidade em meados do século XIX: a sala da maquete São. Paulo em 1841 e aquela Consagrada à Antiga lconografia Paulista.

Para esta última, Taunay encomenda telas a óleo a pintores como Benedito Calixto de Jesus, José Wasth Rodrigues, Hènrique Manzo, entre outros, fornecendo como modelo as folografias de Militão Augusto de Azevedo, que registram aspectos da cidade em 1862 e em 1887. Tendo como base o espaço construído fotograficamente, nas telas são acrescidos, enfatizados ou subtraídos elementos que terminam por constituir um repertório plástico e temático da "cidade colonial" 1 .

Os recursos plásticos próprios da linguagem pictórica naturalista, bem como do referencial fotográfico, atributos de grande aceitação pública, são utilizados numa perspectiva direcionada, ou seja, servem de chaves de acesso aos sentidos que se pretende privilegiar.

A série documental em questão exemplifica a mobilização de suportes iconográficos na montagem das demais salas dedicadas à história de São Paulo. Além das fotografias de Militão, Taunay se preocupa em reproduzir desenhos e gravuras de viajantes, plantas topográficas e mapas, a fim de sub-

\footnotetext{
* As autoras agradecem especialmente ao Prof. Dr. Ulpiano T. Bezerra de Meneses pela leitura crítica e sugestòes enriquecedoras. Foram igualmente valiosas as indicaçôes documentais fornecidas por Miyoko Makino e Jonas Soares de Souza, e o trabalho fotográfico realizado por Wanderlei
} Celestrino.

1. A referência à cidade colonial, aqui, diz respeito unicamente à aparência material. A independência política do país não provocou alteraçōes significativas na capital paulista e, até praticamente o último quartel do século XIX, a cidade ainda guardava traços da vila seiscentista, principalmente no que se refere à configuraçâo arquitetônica (Cf. Toledo 1983). 
sidiar a produção de telas, bem como a confecção da grande maquete em gesso da cidade.

A análise do material iconográfico - entendido por Taunay como vetor de uma função pedagógica que orienta a montagem de representações de cidade articuladas à problemática do nacionalismo - permite redimensionar - papel do intelectual em um museu dedicado a "preservar" a memória pátria e, mais especificamente, a memória de São Paulo.

Este artigo pretende demarcar as noçōes de iconografia implícitas na atividade de Taunay; analisar o repertório colonial a partir de seus atributos plásticos, bem como de suas matrizes textuais e iconográticas; e, por fim, discutir a articulação dessas imagens ao conjunto de representações da modernidade e de identidade nacional emergentes nas primeiras décadas deste século.

Taunay e as Fontes Iconográficas

A série documental em análise pode ser vista como uma amostra das funções atribuídas à iconografia no projeto de exposições do Museu Paulista. Para demarcátas seria útil identificar as noções de documento em geral e de documento iconográfico presentes na prática historiográfica de Taunay.

São certas posturas teórico-metodológicas em relação à iconografia que permitem ao historiador incluir as recriações da cidade na categoria de objetos documentais. Sua historiografia, eminentemente descritiva, visa reconstituições de quadros passados da vida social aptos a serem compreendidos num encadeamento histórico linear e evolutivo.

Essa perspectiva, que mostra claramente a filiação ao pensamento positivista que orientou, em parte, as ciências humanas a partir do final do século passado, trata o documento como portador da própria história, esta como valor imanente do objeto, que necessitaria apenas ser "revelado" pelo historiador. A historicidade do documento fica reduzida, na visão de Taunay, aos critérios de autenticidade e de verossimilhança, ou seja, à sua contemporaneidade com o fato ou quadro histórico vivenciado e à sua plausibilidade. Nesta concepção, as principais tarefas do historiador referem-se à busca de fontes inéditas e à seleção daquelas que respeitam os critérios acima apontados. Estes procedimentos seriam, a princípio, aplicáveis tanto às fontes textuais como às iconográficas.

No entanto, nos trabalhos em que Taunay faz menção à natureza de suas fontes, fica enunciado um tratamento específico das fontes iconográficas, que sugere, ainda que de forma pouco explícita, uma subordinação da iconografia ao texto.

No caso das fontes textuais, procede-se ao confronto interno entre os diversos documentos, visando surpreender eventuais contradições ou inverossimithanças. Quando isso não é possivel - o que parece ser freqüente num quadro histórico de escassa documentação como é o caso do período colonial 
brasileiro -, a autenticidade apoia-se na "probidade e inteligência" do emissor da fonte. Essa confiabilidade no emissor fica evidente nas afirmações de Taunay $^{2}$ em relação a naturalistas, viajantes e artistas como Saint Hilaire, Kidder, Debret; Koster, etc.

Já no caso das fontes iconográficas, o reconhecimento da autenticidade advém da confirmação de documentos textuais abalizados (inventários, crônicas e relatos). Outro critério pode ainda servir de controle caso o documento iconográfico seja de época mas não passivel de ser confrontado, o que o torna singularmente importante: trata-se de verificar as qualidades plásticas da obra, no caso, a aplicação do desenho preciso, detalhista, filiado às representações de cunho realista ${ }^{3}$.

Entretanto, esta relação de subordinação não faz supor que a iconografia era vista por Taunay como menos importante, mas sim como complementar à documentação textual. Tal postura é perceptível nos artigos "As feiras de Sorocaba e a sua iconografia" (1945) e "A mais velha iconografia brasileira do café" (1944). Apesar dos títulos, é somente após uma longa descrição recuperada de fontes textuais, que Taunay se detém na iconografia disponível, vaorizada, no primeiro caso, na medida exata de sua contemporaneidade com o evento la feira de Sorocaba presenciada e desenhada por Hercules Florence, em 1860l, e, no outro, pelas informações específicas que a apresentação visual poderia conferir à descrição textual:

"Como seria do maior interesse se tivéssemos algum desenho reproduzindo o aspecto de uma dessas casas de sorveles, chocolales, chá e café...Quão precioso este flagrante de costumes onde víssemos o ambiente dos nossos cafés primitivos e pudéssemos ter idéia do que era a assistência de seus freqüentadores?" (Taunay 1944:387).

Outra diferença, implícita na montagem das exposições, refere-se ao tratamento das informações advindas dos textos em relação àquelas obtidas da iconografia. As "recriações" pictóricas dos ambientes da São Paulo colonial são categorizadas por Taunay como documentos iconográficos devido ao fato de terem sido "confeccionadas" com base em fontes consideradas "autênticas" pelo historiador e graças à habilidade de seus executores. É o caso das telas encomendadas segundo fotografias ou das que reproduzem literalmente desenhos de viajantes, ou ainda, da execução das esculturas dos bandeirantes Raposo Tavares e Fernão Dias Paes, dispostas no saguão central do edifício do Museu (Cf. Taunay 1937a).

Este procedimento não encontra paralelo na utilização dos documentos textuais: todos que integraram as exposições montadas na década de 20 eram "autênticos" e originais; nunca "recriações" textuais. Tal atitude confirma a noção de documento iconográfico associada predominantemente a uma função de reforço, não somente de um documento textual, mas também evocativa de um quadro histórico. A especificidade da iconografia, neste caso, deve-se ao fato de ela permitir a sintese de informações de naturezas diversas num formato visual. A exploração deste atributo, por Taunay, revela sua aguçada sensibilidade em relação ao poder de comunicação dos suportes iconográficos, quando mobilizados para a produção de sentido.
2. "A contribuição dos viajantes estrangeiros, apesar de sua desvantagem de origem, causada pelas diferenças fundamentais de mentalidade, representa elemento da maior valia $\mathrm{e}$ nada supre seu conhecimento. Sobretudo quando é possivel lançar mão de informantes probidosos e inteligentes como muitos do século XIX, cuja palavra inspira a maior confiança como sejam Tollenaire, Saint Hillaire, Koster, Debret, Kidder, Gardner e Burton entre tantos outros. Graças a estes elementos conjugados de procedêricia nacional e de origem alienígena será possivel ensaiar a reconstituição de aspectos da vida de outrora." (Taunay 1937b:127,128.)

3. Ao comentar a escassez e falta de confiabilidade dos documentos iconográficos relativos a São Paulo, Taunay usa como contraponto a produção holandesa no nordeste do país: "Traz Maurício de Nassau uma legião de pintores, gravadores, desenhistas, arquitetos, naturalistas, representantes de uma civilização notável como a holandesa, onde as artes do desenho tinham desenvolvimento superior ao de Portugal". (Taunay 1949:29).

"No fim da era seiscentista o que conhecemos em matéria de iconografia de São Paulo vem a ser indecisos perfis de montanhas da costa nas vizinhanças de São Sebastião." (Ibidem:31)

Ou ainda, comentando uma gravura do livro de Joris van Spielberg, almirarte holandês do início do séc. XVII: 
"Por acaso entre elas (as gravuras) surge a de Santos e São Vicente, sumamente curiosa como documento histórico, mas bem pouco digna de crédito como tradução da realidade" (Ibidem: 31).
A história descritiva e factual de Taunay, subjacente às exposições, tem como pressuposto teórico as formulações nascidas na discussão em torno da necessidade de melhor documentar a História do Brasil. Capistrano de Abreu, a quem Taunay estava vinculado teoricamente, e os intelectuais ligados ao Instituto Histórico e Geográfico de São Paulo - entidade que tinha como uma de suas atribuições estatutárias proceder ao levantamento sistemático de documentos históricos - proclamavam a pesquisa de novas fontes como imprescindível para a revisão dos períodos históricos mal documentados do país. Por este contexto historiogrático é possivel entender, em parte, o afã de Taunay em recolher documentação ou reproduzíla, quando diretor do Museu Paulista.

A postura "revisionista", aliada ao interesse por um tipo de história ainda pouco explorado na época - a História dos costumes, cujo enfoque assemelhava-se ao da Antropologia ou mesmo da Etnografia - fazem com que Taunay passe a buscar fontes relativas à vida cotidiana no século XIX e descubra, nos relatos e crônicas de viajantes e integrantes de expedições cientifícas, um rico manancial de informações.

Na sua aula inaugural proferida em 1934, na Facüldade de Filosofia, Ciências e Letras da Universidade de São Paulo, ao apresentar o balanço do estado atual dos trabalhos no campo da História da Civilização Brasileira - a cadeira que Taunay passaria a ocupar, ainda que por pouco tempo - o historiador aponta as carências de documentação, principamente para o período colonial, e enfatiza o novo enfoque nas análises empreendidas, voltadas para temas econômicos, artísticos e científicos, assim como relativos aos usos e costumes locais. A iconografia também é citada, na medida em que propicia "...subsídios riquíssimos para a ilustração dos nossos cursos de História da Civilização Brasileira..." (Taunay 1937b: 123).

A História dos usos e costumes, que valoriza a vida cotidiana passível de ser conhecida através das fontes que Taunay enumera, tem seu locus no interior do Brasil - é a partir da constatação de que "se fez a história litorânea e não a do interior", que o historiador vê a necessidade da revisão historiográfica já iniciada por Capistrano de Abreu.

A análise dos argumentos implícitos na eleição da pintura como suporte das exposições e, simultaneamente, no uso da fotografia como documento histórico de apoio permite perceber os vínculos das noções de documento e de iconografia em Taunay com os usos socialmente estabelecidos para 0 suporte pictórico na sociedade dos anos 20, em São Paulo.

Taunay e a Fotografia

Extremamente sensivel à necessidade de tornar hegemônicas as representações de identidade nacional geradas no âmbito dos grupos da elite, Taunay mobiliza um já bem sucedido repertório plástico para a constituição de laços de empatia com o público, ou seja, para utilizá-lo como garantia de receptividade de seu projeto de difusão dos ícones da identidade paulistana. 
Para a valorização do período entendido como colonial não bastava o reconhecimento da História, era preciso cercar as "reconstituições" de São Paulo de atributos pictóricos convencionais, fortalecer-thes a base documental e, sobre esta plataforma, reorientar os sentidos ideológicos dos tipos apresentados.

As manifestações artísticas emblemáticas do "período colonial", como a arquitetura e a pintura, eram alvo de posicionamentos no mínimo ambíguos, no que diz respeito especialmente ao reconhecimento do valor estético destas obras. Até meados da década de 10, além de não serem apreciadas esteticamente, as expressões deste período sofriam, por vezes, de descrédito pela composição social que representavam. O próprio Taunay, endossado por Laudelino Freire, lamenta a deficiência técnica das primeiras pinturas, seu caráter rudimentar, mediocre e quantitativamente pobre (Freire 1916:14, Taunay 1912:61.

$\bigcirc$ estabelecimento de um repertório comum entre público e artista temas, motivos, modos de composição, tratamento cromático, escala do objeto - elucida aspectos restritivos do uso da fotografia e que devem ter pesado sobre a opção de Taunay pelo suporte pictórico.

Quando se comparam as pinturas de São Paulo Antigo com as fotografias que lhes serviam de matriz, o primeiro atributo que salta à vista é o da dimensão. As fotografias $18 \times 24 \mathrm{~cm}$ de Militão não parecem corresponder à escala monumental de uma instituição como o Museu Paulista. É preciso, portanto, ampliar as imagens de São Paulo - não há por que duvidar que a dimensão esteja diretamente relacionada ao grau de enobrecimento, respeitabilidade e prestígio então reconhecidos ${ }^{4}$.

À primeira vista poderia parecer puro preconceito a escolha de pintores, ao invés de fotógrafos, para a tarefa de ampliação das cenas paulistanas. Desde 1870, os fotógrałos retratistas ofereciam ampliações de tamanho natural (Durand 1989:39). Já em 1908, Valério Vieira expunha um panorama da cidade de São Paulo com $12 \mathrm{~m}$ de comprimento. As técnicas fotográficas de montagem, ampliação e fotopintura eram de domínio de profissionais do país. Apesar das possibilidades técnicas da fotografia para a realização de grandes formatos, esta performance tecnológica vinha responder a uma exigência de mercado moldado pela pintura.

próprio Taunay, ao comentar as telas feitas a partir dos desenhos de Hercules Florence, fornece algumas indicações:

\begin{abstract}
"Assim resolveu a Diretoria do Museu copiar exatamente os desenhos do ilustre naturalista em quadros a óleos, ampliando-os para os tornar mais compreensíveis, embora a thes conservar todos os caracteríslicos documentais que os tornam tão preciosos." (Taunay 1937a:79)
\end{abstract}

A associação entre aumento de dimensões com um possível aumento no grau de compreensão da obra evidencia a familiaridade da percepção com os padrões de escala próprios da pintura. As telas em grandes dimensões eram conhecidas e apreciadas pelo público. A decoração de paredes internas de residências com pinturas de paisagens era comum; no meio institucional as telas
4. Nos comentários de Taunay ao edifício do Museu Paulista, a noção de monumentalidade está claramente ligada às grandes dimensões, seja da própria edificação ou de seus elementos decorativos: "Ao soberbo peristilo, enobrecido por vigorosa colunata (Thommaso Gaudenzio Bezzi) adicionou monumental escadaria $e$ galeria, que constituíam quiçá o mais vasto, rico, harmonioso e belo vestíbulo existente na América do Sul. Abriu, no segundo andar do edifício, duas lindas galerias, na fachada anterior ladeando o magestoso Salão de Honra, destinado a receber o grande quadro encomendado a Pedro Américo: Independência ou Morte" (Taunay 1945a:499).

A importância das grandes dimensôes, o prazer estético que proporcionam, sobrepujam argumentos orçamentários: "Pena foi, e muita, que se não houvesse procedido à conclusão do palácio de Bezzi. Em vez de pequeno pavithão que escassamente coroa o alto da colina agora rampada, pavilhâo ereto em ambiente tão vasto quanto majestoso e fronteiro à dilatada e grandiosa perspectiva, possuiria São Paulo o mais imponente $\mathrm{e}$ harmonioso conjunto arquitetônico, não só do Brasil como da América do Sul. (...)Será coisa de se gastarem algumas centenas de contos de réis para a remodelação do jardim contiguo ao Museu, mas imensa compensação estética resultará desta iniciativa" (Ibidem:500) 
5. O consumo de pintura não se circunscreveu à capital, incluindo em seu circuito aquelas cidades enriquecidas pela exploração do café, como é o caso de Ribeirão Preto. A elite desta cidade tinha o hábito de encomendar vistas de suas fazendas bem como pinturas internas decorativas com cenas de paisagens marítimas e naturezasmortas. As exposições eram freqüentes, entre elas as de paisagem. Alfredo Norfini, um dos pintores das encomendas do Museu Paulista, expôs pelo menos três vezes nesta cidade. (Borges 1983: $80,85,194,200$ ). monumentais eram obrigatórias desde a introdução das cenas de batalha, após a Guerra do Paraguai. Victor Meireles, no final do século, abre a firma Meireles \& Langerock, com o objetivo de produzir panoramas - o primeiro deles possuía $115 \mathrm{~m}$ de comprimento (Durand 1989:22). . $^{5}$

Acrescentem-se a isso algumas das características próprias de uma pintura vinculada ao desenho, ao detalhamento, onde os planos e as formas são bem definidos, onde o uso do pincel de maneira regular e homogênea dota a imagem de características descritivas. Nesse caso, a grande dimensão permite um melhor aproveitamento da composição analítica, incentivando a observação de pequenas unidades dentro do conjunto, de que o exemplo mais notável é a tela de Benedito Calixto "Inundação da Várzea do Carmo em 1892", que apesar de não pertencer à série de pinturas encomendadas por Taunay, figurava com estas na sala dedicada à Antiga lconografia Paulistana.

Não menos relevante é o fato de a pintura se apresentar, tradicionat mente, como objeto de prestígio nos museus, podendo-se supor que a ela será creditado, mais facilmente, o estatuto de peça autêntica. É em torno da idéia de autencidade, entendida enquanto testemunho remanescente do passado, que se acoplam novos significados quase sempre legitimadores da ordem social vigente (Horne 1984: 14-15). Através da pintura, Taunay reforça o sentido de documento histórico conferido a uma produção contemporânea. A fotografia, entendida como objeto em série, apesar de ser utilizada como documento, não poderia usufruir da credibilidade da pintura. O Decreto Estadual $n^{\circ} 249$ de 26 de julho de 1894, que aprova o Regulamento do Museu Paulista, enumera as categorias de documentos iconográficos que deveriam compor o interior do edifício:

"Art.3,Parag. 1: Nas galerias e lugares apropriados do edifício serão colocadas as estátuas, bustos ou retratos a óleo de cidadãos brasileiros que, em qualquer ramo de atividade, tenham prestado incontestáveis serviços à Pária e mereçam do Estado a consagração de suas obras ou feitos e a perpetuação de sua memória.|...)

Parág. 3: Desta galeria de homens ilustres não farão parte senão os já falecidos que tenham a seu favor um júzzo definitivo da História." (Decreto Estadual 1894:204).

A presença da fotografia no Museu Paulista restringia-se exclusivamente às áreas de História Natural e Etnográfica, mais especificamente às publicações na Revista do Museu. Paulista e aos trabalhos de coleta de material para as coleções de estudo e de exposição. Mesmo nesse campo, a ênfase na produção documental recaía sobre os exemplares materiais recolhidos ao acervo e sobre o "diário" de viagem, que deveria conter "nołas ou observações", escritas pelo naturalista responsável. No âmbito da chamada História Pátria, ressalva deve ser feita à presença, no Museu, de uma fotografia do Presidente do Estado Bernardino de Campos. A excepcionalidade deste uso da fotografia fica implícita na própria indicação que faz Hermann von lhering, então diretor do Museu, em artigo no primeiro volume da Revista do Museu Paulista, e possivelmente se justifica pelo fato de se tratar de personalidade política ainda viva, atuante e presente na inauguração de abertura ao público do Museu:
"No corredor principal está colocado, em fotografia, o retrato do dr. Bernardino de Campos..." (|hering 1895:26). 
$\mathrm{Na}$ Europa, o uso de folografias em museus estava associado, desde a segunda metade do século XIX, à prática preservacionista crescente neste período. A fotografia era reconhecida como um meio eficaz de conservação do passado. Os grupos ligados aos movimentos de conservação cresceram paralelamente às sociedades de fotografia. Em 1897, a National Photographic Record Association depositava no Museu Britânico as fotografias de cenas consideradas de interesse para o conhecimento do passado. Esse parentesco entre fotografia e preservação estendia-se a países como Estados Unidos, Bélgica e Alemanha (Walsh 1992:71). É ainda na Revista do Museu Paulista que se encontra nova menção ao uso da fotografia em museus da Europa, agora com a função de apoio aos objetos de exposição. O Museu Botânico de Berlin apresentava fotograficamente, em exposição, detalhes ampliados de cortes de madeira, amostras de terra, etc. (Taubert 1895:164).

A aquisição de conjuntos folográficos reproduzindo pinturas e desenhos faltantes nas coleções de originais dos museus europeus, e que serviriam como modelo substitutivo das gravuras e litografias utilizadas por praticantes do desenho na época parece ter sido outra aplicação comum da fotografia no século passado6.

No Museu Paulista este tipo de uso da fotografia é de certa forma fomentado por Taunay, que providencia a reprodução fotográfica maciça de documentos originais não disponíveis na instituição. Por outro lado, a importância da fotografia como documento original é reconhecida pelo historiador, na medida em que este meio passa a ser o responsável direto pelo maior afluxo de documentos iconográficos, principalmente a partir de 1858. No entanto, os autores das imagens fotográlicas não são citados com tanta freqüência, e nem suas qualidades exaltadas como no caso dos viajantes. A sensibilidade do desenhista em registrar a cena antiga, interpretando "com objetividade" e, portanto, veracidade o tema, parece ser um dos índices de valorização do documento. A fotografia permanecerá na categoria dos documentos de apoio, seja para conferir um lastro documental aos objetos de exposição, seja para servir diretamente de modelo para a sua produção ${ }^{7}$.

Apesar da reconhecida capacidade da fotografia em reproduzir oticamente aspectos da realidade, a função de "fixar" cenários históricos ou personalidades no Museu, logo preservá-los da ação do tempo, permanece como uma tarefa prioritária da pintura. É possível encontrar nas "reconstituições" pictóricas da cidade de São Paulo a intenção de preservar simbolicamente o aspecto colonial da cidade pré-republicana, que por essa época já vinha sendo destruída e cuja proteção começa a ser esboçada juridicamente só na década de 30, com a organização de instituições de proteção ao patrimônio cultural, entre elas o SPHAN - Serviço do Patrimônio Histórico e Artístico Nacional, com ante-projeto da lei elaborado por Mário de Andrade, a pedido do Ministro da Educação Gustavo Capanema (Lemos 1993: 17).

Mas a opção de Taunay pela pintura, de preferência à fotografia, significava mais do que uma resposta conservadora às pressões da tradição museo-
6. Alfredo Galvão em sua coletânia de documentos da Escola de Belas Artes referentes ao pintor João Zeferino da Costa transcreve uma carta, de 1875 . dirigida ao Conselheiro Antonio Nicolau Tolentino, diretor da Academia Imperial de Belas Artes, onde há uma citação extensa sobre estas aquisições "Não escapará por certo à alta inteligência de V.Exa. e dos ilustres Professores quão pouco satisfaça para o bom ensino dos primeiros elementos de desenho, o uso de dar-se aos alunos, para copiar, litografias, gravuras, etc.etc., como até o presente o faz a nossa Academia. Essas estampas, aliás feitas com grande nitidez, são entretanto desprovidas daqueles requisitos $\mathrm{e}$ méritos artísticos que é mister que o estudante aprenda desde o princípio de sua carreira; podendo-se portanto substituir pelos desenhos das mãos dos grandes Mestres e de cujo mérito hoje em dia se convencem todos os que professam as Belas Artes. Sendo, porém, muito difícil, ou extraordinariamente dispendioso obter-se tais tesouros, os principais institutos da Europa recorreram às fotografias inalteráveis, intituladas "facsimile", das obras dos antigos e célebres Mestres, como já o fizeram as Academias das Belas Artes de Paris, Bruxelas, de $\mathrm{Hei}$ delberg, de Düsseldorf, de Bonn, de Lyon, de Besançon, de Reims, de Florença, de Perugia e de São Lucas de Roma, além de trinta e quatro escolas de desenho nos distritos do Sena, como também 
na Rússia, na América do Norte, etc. $\mathrm{E}$ mais ainda, muitos museus não possuíam uma coleçào completa desses desenhos originais a enriqueceram fazendo aquisiçôes dessas fotografias, entre as. quais os Museus de Berlin, de Brensuik, de Dresden, de Monique, de Stuttgart, de Praga de Frankfurt, de Viena de Darmstadt, de Hensinglton, de Nuremberg, Weimar, British Museum, Museu Industrial de Lyon, de Lille, do Montpellier, de Nimas, de Toulon, Nancy, Marselle, Narbonne e Amsterda (Apud Lee 1991:21-24)

7. O uso da fotografia como marriz para a pintura é praticamente contemporâneo da própria invenção da fotografia. Desde 1841 são produzidos daguerreótipos - as "academias" para uso de artistas, substituindo os mode los vivos (Newhall 1982:31).

8. O circuito de exposições em São Paulo e no Rio de Janeiro, na sua grande maioria não especializado, incluía lojas, ateliês fotográficos antiquários, livrarias, charutarias, hotéis, teatros, cinemas, o saguão da revista $A$ Cigarra, a Galeria Artística, o Liceu de Artes e Ofícios, salas e salões temporariamente vagos e os próprios ateliês dos artistas (CF. Durand 1989:45; Tarasantchi 1981:77).

9. Nas duas primeiras décadas deste século, realizaram mostras individuais, em São Paulo, Eliseu Visconti, Antônio Parreiras, Pedro Weingartner Benjamin Parlagreco,
lógica.Apesar de informal, o mercado de pintura no Brasil estava constituído desde o final do século XIX. Além das encomendas institucionais e particulares, que não eram poucas, havia um circuito não especializado de exposições, o que nos permite supor o acesso a um público também heterogêneo ${ }^{8}$.

A partir da década de 1910, o intercâmbio artístico entre São Paulo e Rio de Janeiro tomou impulso, e existia espaço até mesmo para aqueles considerados ainda em período de formação, seja através de exposições individuais que aconteciam regularmente, seja através de grandes exposições coletivas.

As exposições não eram apenas oportunidade para angariar prestígio, mas uma forma bastante eficiente de venda dos trabahos. A aquisição de pinturas tornara-se um hábito, sendo raras as exposições que terminavam sem terem todas as suas peças vendidas?.

A prática da pintura e do desenho d'aprés nature transcendia o campo da formação artística para se disseminar como disciplinas de apoio em cursos oferecidos por instituições profissionalizantes como o Liceu de Artes e Ofícios, ou como refinamento da educação de um público leigo através de cursos oferecidos em escolas e ateliês particulares ${ }^{10}$.

A pintura que participava intensamente deste circuito não era outra senão aquela ligada ao gênero de paisagem e à estética naturalista. Sua comercialização estava, por sua vez, amparada financeiramente por representantes dos grupos sociais com poder político e econômico e pela crítica de arte, importante formadora de opinião na época e com presença regular nos jornais e revistas de grande circulação ${ }^{11}$. O Museu Paulista estava inserido nesta esfera de poder da burguesia paulistana, recebendo de Washington Luís, então Governador do Estado, a verba necessária para a formação da Seção de História Nacional e para a montagem das salas de exposição, tendo em vista as comemorações do centenário da Independência em 1922.

Será neste universo plástico tão bem adaptado ao gosto do grande público que se vão movimentar os pintores envolvidos pelas encomendas do Museu Paulista. A assimilação das qualidades pictóricas será reforçada ainda pela familiaridade do público também com as fotografias de Militão, divulgadas em periódicos, ilustrando matérias retrospectivas sobre a cidade.

A série de pinturas São Paulo Antigo, estruturada a partir de um estilo socialmente difundido, é capaz de abarcar um projeto de difusão maciça do ideário nacionalista. Ao contrário das estratégias discriminatórias que a autonomia do objeto artístico tenderá a incentivar após as experiências modernistas no Brasil, a estética naturalista se oferece como uma via de comunicação entre a elite e os demais grupos sociais. Ela admite o uso do código da experiência cotidiana e do repertório pictórico tradicional para a compreensão das obras de arte:

"O gosto acadêmico pelas representações conhecidas e reconhecidas equipara-se ao gosto popular para exigir uma representação ajustada aos cânones de um estilo já apropriado, e para rejeitar a arte moderna que, ao afirmar sem concessões a autonomia absoluta do modo de representação (isto é, do estilo), tende a bloquear a interpretação assimilativa que a mutifuncionalidade da pintura tradicional autorizava, e a exigir uma contemplação concentrada apenas em suas propriedades formais. Uma obra aparece como semelhante ou realista quando as regras que regem sua produção coincidem com a definição vigente da representação objeliva do mundo, 
ou melhor, com o sistema de normas sociais de percepção insensivelmente inculcadas através do convivio prolongado com representaçōes produzidas segundo as mesmas normas. Destarte, ao conferir à fotografia um certificado de realismo, nossa sociedade está apenas confirmando para si mesma a certeza tautológica de que uma imagem ajustada à sua representação da objetividade é de fato objetiva." (Bourdieu 1987:2921.

Em São Paulo de então, a estética naturalista conjuga-se ao regionalismo fundando uma atitude considerada moderna, que consistia em forjar uma memória nacional a partir dos elementos emblemáticos do período colonial. Em seu livro sobre a capital paulista nos anos 20, Nicolau Sevcenko ressalta o modismo em que se transformou a corrente intelectual nativista e regionalista a partir da encenação da peça O Contratador de Diamantes, de Afonso Arinos. A peça exultava a saga bandeirante e serviu de motivação para fortalecer a oligarquia cafeeira frente ao crescimento econômico, em vias de se tornar também político, da burguesia industrial de origem imigrante. Saraus sertanejos e excursões pelo interior de São Paulo e de Minas mobilizavam as elites interessadas em estudar e conhecer exemplares do passado colonial. A História, segundo Sevcenko, estava na ordem do dia e as estéticas que a veiculavam, garantiam o trânsito da cultura popular no circuito das elites e no imaginário coletivo (Sevcenko 1992:247).

Taunay soube explorar, conscientemente ou não, o papel fundamental da pintura como vetor das representações associadas ao ideário nativista. A escolha dos recursos plásticos e temáticos próprios do gênero paisagístico e regionalista para compor a ambientação de São Paulo Antigo está relacionada com o alto grau de estabilidade que os padrões iconográticos acima tratados atingiram no interior da sociedade paulistana.

Se as noções de iconografia em Taunay servem de referencial para a compreensão de suas encomendas, os mecanismos internos de montagem das representações da cidade e as funções específicas que cumprem no Museu só adquirem pleno significado se observados no interior da própria série de pinturas. Para tanto, é necessário caracterizar e analisar seus atributos visuais, especialmente aqueles elementos alterados em relação aos originais fotográficos.

O encaminhamento dos problemas aos quais estas representações articulam-se pressupõe uma abordagem pontual de cada uma destas características, já que guardam sentidos específicos dentro do conjunto da série.

\section{A Montagem da "Cidade Colonial"}

\section{A série fotográfica}

Das fotografias selecionadas por Taunay para servirem de matrizes da série de pinturas São Paulo Antigo, onze foram extraídas do Álbum Comparativo da Cidade de São Paulo - 1862-1887, de autoria de Militão
Aurélio de Figueiredo, Georgina e Lucílio Albuquerque, Pedro Bruno, Carlos Chambelland, Carlos Oswald, Dakir Parreiras, Edgar Parreiras, Helios Seelinger, Levino Fazeres, entre outros. Benedito Calixto e Jonas de Barros integravam a comissão artística da coletiva Exposiçâo de Belas Artes e Artes Industriais de São Paulo, realizada em 1902. Bertha Worms, Benedito Calixto e grande parte dos paisagistas de maior prestígio estavam nas coletivas Primeira Exposiçâo Brasileira de Belas Artes e Segunda Exposicão Geral de Belas Artes, realizadas no Liceu de Artes e Ofícios entre $1911 \mathrm{e}$ 1913 (Cf. Chiarelli 1989: 150, 152).

10. José Wasth Rodrigues dava aulas de desenho para homens em 1916. Também nesse mesmo ano Nicola Petrilli era sócio na Escola Novíssima. Bertha Worms e Alfredo Norfini davam aulas em seus ateliês desde o início do sécu1 o ( C f . C h i a relli 1989:143,146,147).

11. A burguesia paulistana estava envolvida nos patrocínios das exposiçôes, na fundação da Sociedade de Cultura Artística, na Liga da Defesa Nacional, nas articulações de apoio à arquitetura neocolonial, na seleção de pintores beneficiados pelo Pensionato Artístico do Estado, no projeto de criação de um Instituto Paulista de Belas Artes, etc (Cf. Chiarelli 1989:134-144). 
12. Sabe-se da existência de pelo menos três álbuns intitulados São Paulo Antigo (Museu Paulista, Instituto Histórico e Geográfico de São Paulo e coleção particular Jamil Nassif Abib). Em dois deles constam legendas manuscritas e apenas um possui uma listagem impressa. Quanto à procedência, não se têm informações: se foram montados também por Mỉlitão (hipótese mais remota) ou por alguma casa publicadora de São Paulo; se foram comercializados; ou quando foram produzidos (certamente não são contemporâneos das fotografias que os constituem, de 1860 , visto o título que trazem). As fotografias de Militão, que integram o Album Comparativo da Cidade de São Paulo, foram reeditadas $\mathrm{em}$ 1982, com o acréscimo de imagens publicadas em 1914, pela Casa Duprat (São Paulo 1982).
Augusto de Azevedo (1 887) e cinco do álbum denominado São Paulo Antigo ${ }^{12}$, montado também com imagens do mesmo fotógrafo. Integram ainda a série duas fotografias sobre as quais não se tem notícia nem da autoria e nem se compunham algum tipo de publicação.

A seleção das imagens fotográficas por Taunay não foi aleatória; um exame da série escolhida esclarece sobre o tipo de imagem urbana pretendida para compor a exposição referente a São Paulo Antigo.

Do álbum comparativo de Militão, é significativo notar que Taunay seleciona, de um universo de sessenta imagens, apenas as parciais de 1862, que retratam ruas próximas ou localizadas no triângulo central da cidade. Dentre essas, sua opção recaiu justamente sobre as ruas em que os vazios urbanos são predominantes (ausência de pessoas e veículos transitandol e onde a ordenação espacial é bem definida e homogênea - lotes e gabaritos que não apresentam discrepâncias de dimensões no seu conjunto - apesar da ausência de pavimentação.

Pode-se dizer que essa seleção descaracteriza totalmente a intenção de Militão quando da montagem de seu álbum. A dimensão temporal introduzida pela justaposição de folografias com um intervalo de vinte e cinco anos, que caracteriza a proposta comparativa original, direciona a leitura do conjunto de imagens, evidenciando um processo de mudança. É a percepção das diferenças que dá o sentido comparativo.

Em linhas gerais, são as obras de infra-estrutura - alinhamento, pavimentação e alargamento de ruas - e o adensamento urbano - pessoas e veículos nas ruas, gabarito mais elevado das edificações - que distinguem as imagens de ambos os períodos. $O$ chão batido e sem calçadas das ruas em 1862 é pavimentado e ganha calçamento de pedra; as modestas luminárias a gás, penduradas nas casas, contrastam com os postes mais altos, presentes já em 1887; as edificações baixas, de no máximo dois andares, comuns em 1862, dão lugar a outras, de gabarito mais elevado (três a quatro andares); os vazios urbanos, por sua vez, desaparecem, denotando o adensamento da cidade em 1887.

A recorrência de tomadas panorâmicas (mais de um terço do álbum) aliada a legendas que indicam, por vezes, até mesmo o ponto de vista do fotógrafo fazem com que a articulação espacial dos logradouros da região central seja perceptivel. Do mesmo modo, as tomadas de um ponto externo à cidade destacam os limites e a conformação topográfica do núcleo urbano. Acresce-se a isso a presença, nas fotografias de 1887, dos bairros recém-edificados ou em expansão, como Campos Elíseos, Santo Amaro e Bela Vista.

- No álbum de Militão tem-se, assim, a imagem de uma cidade articulada, em processo de modernização - pelo menos no que diz respeito ao seu desenho urbano - e em expansão.

A série fotográfica montada por Taunay, visando a feitura das telas encomendadas, ao desprezar todas as panorâmicas e, principalmente, os registros de 1887 (com exceção da fotografia do Largo de São Bento), conforma uma imagem praticamente oposta àquela do álbum comparativo: uma cidade vazia, estável, sem quaisquer sinais de crescimento ou mudanças. 
A partir de uma configuração espacial urbana já sugerida na seleção fotográfica de Taunay, a série pictórica irá reproduzir de forma mais bem acabada aquelas características consideradas definidoras do espaço "colonial".

Observa-se uma distribuição eqüitativa dos motivos no quadro. Estes são apresentados dispostos ao longo da rua de forma que se perceba a regularidade dos lotes e a unicidade do padrão volumétrico e dos componentes arquitetônicos. As diversidades formais e funcionais não comprometem a unidade do cenário. Trata-se de um espaço urbano homogêneo, sem expressão física de desestruturação, logo, um espaço estabilizado. Simultaneamente, a ausência de sinalização (por exemplo, placas de identificação de estabelecimentos comerciais, anúncios, etc.) pressupõe alto grau de interação social.

Motivos isolados como o muar estacionado no alinhamento da rua Rua das Flores em 1860, de Henrique Manzo (fig. 1) e Ladeira do Colégio em 1860, de Benedito Calixto - o tropeiro montado em séu cavalo - Piques em 1860 (fig. 2) e Igreja da Boa Morte em 1860, de Henrique Manzo - ou reduzidos agrupamentos - Pátio da Sé e lgreja de São Pedro, de Wasth Rodrigues (fig. 3) - agem como elementos dinamizadores que, no entanto, reforçam a atmosfera de inalterabilidade da paisagem urbana já que se localizam, na sua grande maioria, próximos às diagonais ou ortogonais do quadro.

A rua é o elemento que articula o espaço urbano, produzindo o efeito de grandes superfícies. O primeiro plano, mesmo quando valorizado pela proximidade, nunca funciona autonomamente, servindo para aprofundar a espacialidade do quadro. A homogeneidade espacial resulta na criação de um efeito de horizontalidade, unificando, e portanto ampliando, o espaço representado, além de subordinar efeitos opostos, como, por exemplo, a verticalização produzida pelo conjunto de edifícios.

A presença da arquitetura e do alinhamento das ruas como elementos de ordenação espacial não esconde a topografia do espaço urbano declives e planícies são claramente representados.

A organização da cidade como uma grande superfície por si só enfatiza espaços vazios, que são ainda mais acentuados pela subtração de elementos móveis, basicamente veículos e tipos humanos presentes na fotografia Trecho Final da Antiga Rua do Rosário em 1858, de Wasth Rodrigues; Ruas do Carmo e da Boa Morte em 1860, de Jonas de Barros; Largo de São Bento em 1880, de Nicola Petrilli e Rua da Quitanda em 1858, de Benedito Calixto.

Por outro lado, o território urbano é representado de maneira redutora. Evita-se qualquer percepção de espaço em crescimento ou de aspectos de modernidade indiciais de uma cidade que já demonstra, ainda que embrionariamente, uma diferenciação entre centro e bairros. Na tela Largo do Ouvidor em 1858, de Henrique Manzo, o casarão distante, já fora do perímetro intensamente urbanizado, é substituído por um fundo de vegetação (fig.4) ; Benedito Calixto retrocede à rua de terra batida na tela Rua da Cruz Preta em 1858, quando a fotografia de Militão mostra as reformas para alinhamento e pavimentação (fig. 5 ); 
Nicola Petrilli, por sua vez, camufla os trilhos de bondes na tela Largo de São Bento em 1880.

É notável a ausência de tomadas panorâmicas do ponto de vista externo à cidade, que privilegiariam a visualização do núcleo urbano. A cidade aparece assim articulada ao espaço rural de forma complementar. Em telas como Piques em 1860 (fig.3) e Largo do Ouvidor em 1858 de Henrique Manzo, ou a Ladeira do Colégio em 1860, de Benedito Calixto, as ruas da cidade são os caminhos de saída para o sertão, o lugar de passagem de mercadorias trazidas pelas tropas, representam a integração territorial comandada pelo campo, e não o elemento que indicaria a dinamicidade urbana.

A preocupação de Taunay seja com a autenticidade das fontes documentais ou com a obtenção de dados descritivos sobre o período pré-republicano estava perfeitamente afinada com um tipo de pintura que se propunha a reconstituir, através da observação direta ou da pesquisa, tipos humanos e ambientais característicos do país. Visualmente, as afinidades entre os cenários urbanos representados nas telas de São Paulo Antigo e as cenas de paisagem produzidas pela pintura de cunho naturalista podem ser aferidas em vários níveis.

Ainda que representado plasticamente de forma diversa, na pintura de paisagem observamos a constituição do espaço como superfície contínua, onde são freqüentes os planos horizontais amplos e homogêneos - superfícies terrestres ou marinhas - contrabalançados pela presença de elementos isolados em diagonais ou verticais.

O reforço da estabilidade espacial, que nas encomendas de Taunay é resultado do posicionamento estratégico de figuras como o muar, o carro de boi, o tropeiro, etc., possui o seu equivalente, na pintura de paisagem, no destaque de pequenos motivos pontuais, como um barco de pesca ancorado à beira da praia, um animal doméstico pastando solitário no campo, uma árvore sobressaindo-se no descampado da planície, etc.

A presença de espaços vazios nas imagens urbanas também tem como um de seus referenciais as paisagens marítimas ou campestres, onde se estendem grandes superfícies, cujo detalhamento ou variações de textura não chegam a comprometer a contigüidade espacial.

Em uma abordagem pictórica como a da série São Paulo Antigo, que procura na visualidade fotográfica seus padrões de verossimilhança, elementos formais como cor e desenho não são de menor importância. Entretanto, - tratamento plástico destas imagens está subordinado aos seus elementos temáticos. A linguagem tem, nesse contexto, uma aplicação instrumental na organização do sentido. $O$ desenho, entendido aqui no seu nível técnico de produção, define a forma, permitindo a identificação precisa do motivo. A cor, por sua vez, submetida ao traçado, transforma-se em atributo do tema.

A ênfase no céu, que na pintura de paisagem chega a ocupar dois terços do quadro, ressurge nas telas encomendadas através do enriquecimento da superfície amorfa do céu fotográfico: fortes tonalidades de azul ou mesmo variações cromáticas e volumétricas. O cromatismo dos ambientes urbanos é marcado pelo uso de uma patheta clara, de cores primárias, tonalidades brithantes, evitando-se cores neutras ou a aplicação de velatura. Há uma preferên- 
cia evidente pela representação de uma atmosfera ensolarada, que acentua o colorido do casario e a presença de ocres.

Desde o final do século XIX, quando a pintura de paisagem rompe com a camisa de força imposta pelos ateliês da academia, até as duas primeiras décadas deste século, os estudos da ação da luz sobre os objetos desenvolveram-se com a finalidade de representar o que seria a cor local, fruto da observação direta e da captação da luminosidade e colorido específicos da paisagem brasileira. Nas telas encomendadas podemos ver aplicados os resultados já cristalizados desta preocupação com um cromatismo próprio da natureza do país. A cor se transformou, na década de 20, em um dos índices de expressão da nacionalidade. Era o talento do artista (misto de sensibilidade e técnica) e o seu conhecimento da realidade sensivel que tornariam possíveis a tradução de uma atmosfera tipicamente brasileira.

Para a montagem das representações da cidade de São Paulo, Taunay se utiliza não somente das regras definidas pela pintura e pela fotografia, como manipula certos motivos apresentados pela matriz fotográfica e introduz novos elementos oriundos de outras matrizes. Por sua vez, motivos como a arquitetura vernacular e as igrejas, ao serem transportados para as telas, sofrem alterações de modo a enfatizar o aspecto colonial com que se quer dotar a cidade de São Paulo do século XIX.

Os traços que identificam a morfologia arquitetônica do período colonial são ressaltados na composição pictórica através de alterações formais, como no caso do alongamento dos beirais projetando áreas de sombra na rua - Rua das Flores em 1860 (fig. I) e Igreja da Boa Morte em 1860, de Henrique Manzo; Largo e Matriz do Brás em 1862 e Rua da Constituição em 1862, de Benedito Calixto - e no realce da estrutura dos muxarabis e balcões - Rua do Rosário em 1858, de Wasth Rodrigues (fig.6), ou ainda, na ampliação desproporcional das janelas em relação às figuras humanas - Rua da Quitanda em 1858 e Paço Municipal, Forum, Cadeia de São Paulo em 1862, de Benedito Calixto.

Aliado à exploração da luz e áreas de sombras na representação de ambientes ensolarados, o detalhamento dos elementos arquitetônicos sugere uma relação orgânica e harmoniosa dessa arquitetura com o seu meio - tropical, brasileiro - evidenciando a funcionalidade das edificações vernaculares.

Para a representação da arquitetura, a escolha de Wasth Rodrigues não poderia ter sido melhor. $O$ movimento de recuperação e pesquisa da arquitetura colonial, iniciado já na década de 10, tendo à frente o arquiteto Ricardo Severo ${ }^{13}$, contara com a colaboração deste pintor que, em viagem pelo interior do país, documenta os exemplares da arquitetura praticada no período colonial. Esse movimento caracterizava a arquitetura vernacular como extremamente funcional, contrapondo-a ao ecletismo, numa crítica ao abuso da ornamentação que mesclava elementos de vários estilos arquitetônicos. Os beirais alongados, os azulejos, os alpendres e muxarabis, por exemplo, não apenas compunham decorativamente as fachadas, mas representavam uma resposta
13. O movimento de "Renascença da Arquitetura Colonial" teve em Ricardo Severo um dos seus principais expoentes, ao lado de arquitetos como José Mariano Filho e Nereu Sampaio. Desde a década de 1910 , através de palestras e artigos publicados em jornais (A Tradição, conferência no Instituto Histórico e Geográfico de São Paulo, 1911; A Arte Tradicional no Brasil, conferência na Sociedade Cultura Artística, 1915; "Da Arquitetura Colonial no Brasil", artigo publicado em $O$ Estado de São Paulo, 7 de setembro de 1922) Ricardo Severo procura divulgar seus estudos relativos à arquitetura colonial e as fontes disponíveis para tal. (Cf.Amaral 1992, Lemos 1985). 
14. A partir do último quartel do século XIX, observamos um significativo crescimento da produção fotográfica de "vistas de São Paulo" vendidas avulsas ou em álbuns. $\mathrm{E}$ na primeira década deste século a fotografia já começa a ser integrada à produção editorial. Os almanaques anuais publicadós em São Paulo, de ampla circulação, são os primeiros a trazer imagens fotográficas de edifícios públicos, personalidades políticas, bem como de estabelecimentos comerciais e industriais que anunciavam neste veículo. $O$ mesmo ocorre com algumas revistas ilustradas como O Correio Literärio e Bibliográfico da Livraria Laemmert $c$ a Illustração Brasileira (de $1905 \mathrm{em}$ diante) (Cf. Lima 1991:59). técnica à necessária adaptação ao meio físico, como preservar as habitações do calor e das chuvas, sem comprometer a intimidade dos ambientes internos. Procurava-se, na prática vernacular, o fio de uma tradição nacional.

Já no caso das igrejas, não são os traços arquitetônicos que as recriações pictóricas buscam evidenciar. Se elas estruturam, via de regra, o último plano fotográfico, nas telas chegam a ser "reconstituídas" quando não aparecem nítidas ou por inteiro - Aspecto da Rua do Rosário à Noite em 1862, de Wasth Rodrigues. Nessa medida, os edifícios religiosos conformam os marcos físicos e mesmo político-culturais do espaço representado, marcando as diferenças entre o desenho urbano da cidade colonial em relação ao da republicana que começa a se delinear no último quartel do século XIX. É por essa época que os recém-construídos edifícios destinados a abrigar as instituições laicas la administração pública, as escolas públicas e particulares, os institutos de pesquisa, etc.) passam a substituir as igrejas no papel de marcos referenciais para o contexto urbano, indicando os novos contornos das relações de poder na cidade e as redefinições entre os espaços público e privado.

As telas "reconstituindo" o passado da cidade têm como parâmetro contemporâneo de transformação urbana o repertório de imagens fotográficas cuja circulação não era desprezível. Na produção de álbuns e postais fotográficos de São Paulo as inúmeras igrejas localizadas na área central da cidade não integram os motivos selecionados para compor esse tipo de produção editorial; em seu lugar, figuram os edifícios da municipalidade - as Secretarias da Agricultura, da Justiça, do Tesouro, o Teatro Municipal, etc. A fotografia, nesse contexto, cumpre a função de dotar São Paulo de uma imagem moderna e sobretudo laica, em que são realçados as inovações urbanísticas los loteamentos residenciais planejados, as reformas no vale do Anhangabaú) e os exemplares da "nova arquitetura". Todo e qualquer vestígio do tipo de ocupação anterior é banido ${ }^{14}$.

Dos elementos acrescidos ou substituidos na transcodificação da imagem fotográfica para a pictórica - o carro de boi, os muares transitando pelas ruas centrais da cidade, os negros descalços carregando cestas na cabeça, ou acompanhando o bangüê, as damas postadas nos balcões dos sobrados - a figura do tropeiro é a mais significativa. Nas obras de Wasth Rodrigues, ele substitui a dama de sombrinha na tela Pátio da Sé e lgreja de São Pedro em 1858 (fig.3), e é introduzido em outra - Rua do Rosário em 1858 (fig.6) - juntamente com demais tipos da sociedade colonial. Aparece também na tela de Henrique Manzo, Piques em 1860 (fig.2). Em todas, o tropeiro tem um lugar de destaque, seja posicionado próximo ao centro geométrico da composição, seja ocupando o primeiro plano. Os atributos que imediatamente o identificam - o chapéu de abas largas, a capa longa e o cavalo - nos dão o indício de que já se trata de um tipo constituído, cujas matrizes remontam à produção iconográfica de viajantes do início do século XIX. Trata-se, portanto, de um motivo gerado fora da visualidade fotográfica, num circuito diverso, demonstrando a mobilização de fontes a que procede Taunay na "produção" de um documento iconográfico. 
MUSEUS 
MUSEUS 
É o próprio Taunay que nos ajuda a inventariar parte das obras em que o tropeiro aparece, ao noticiar as fontes iconográficas disponíveis no Museu Paulista para ilustrar a história da expansão territorial do sudoeste do país. Ao que tudo indica, os viajantes estrangeiros /Handeršon, Chamberlain, Kidder) e, notadamente aqueles que integraram a Missão Francesa (Debret, Florence, Taunay, Rugendasl, foram os primeiros a fixar, em desenhos e gravuras, a figura do tropeiro ${ }^{15}$.

$\mathrm{Na}$ iconografia dos viajantes, tal como vemos nas telas, estão inscritos os atributos acima elencados: o ocultamento do rosto, devido ao chapéu de abas largas, concorre para que o tipo do tropeiro seja um modelo mais abrangente, graças à não particularização dos traços fisionômicos. Nas telas e nas suas matrizes, raramente o tropeiro aparece sozinho ou em repouso, na maioria das vezes, é retratado montando a cavalo e sempre acompanhado dos muares, em cenas de negociação ou na estrada.

Nessa recriação pictórica da cidade, a figura do tropeiro é o elemento dinâmico, transitando pelas ruas-caminhos de São Paulo Antigo. Ele presentifica o sertão no meio urbano, superando assim, imaginariamente, a contradição entre campo e cidade que começa a evidenciar-se com o desenvolvimento da industrialização, colocando em xeque o modelo econômico calcado exclusivamente na atividade agro-exportadora sustentada pelas elites oligárquicas.

Nas fontes legadas pelos viajantes, se os desenhos dão conta da caracterização física, ressaltando uma postura dinâmica, nos relatos textuais a imagem do tropeiro é completada pela descrição dos traços de sua personalidade e de seu modo de vida pelos sertões do sul. Na verdade, ambas as fontes - iconográficas e textuais - partem de um mesmo padrão de realismo cujo modelo de conhecimento embasava-se por uma atitude classificatória do mundo: a descrição dos elementos autóctones pelos naturalistas viajantes é extremamente rica em detalhes, fornecendo dados que nunca antes haviam sido levantados. Essas fontes são fruto da ótica de quem se propõe a "conhecer cientificamente" o novo, ou melhor, aquilo que diferia da cultura e do modo de vida europeus.

É essa documentação que fundamenta as mais conhecidas obras de história que tratam do tropeiro, dentre as quais destacam-se as de Taunay lem seus volumes sobre a História do Café. História das Bandeiras, História de São Paulo, nos Relatos Sertanistas e em inúmeros artigosl, e outras, mais específicas ou recentes, como as de Aluísio de Almeida (Vida e Morte do Tropeiro, 19711, José Alípio Duarte (Tropas e Tropeiros na Formação do Brasil, 1961). Alcântara Machado (Vida e Morte Bandeirante, 1919). Todas, sem exceção, compartiIham das mesmas fontes "primárias" sistematizadas e reproduzidas por Taunay para integrar o acervo do Museu Paulista — os relatos, em muitos casos acompanhados de ilustrações de Saint Hilaire, Kidder, Flechter, Handerson, Calogeras, Rugendas, Burton, Mawe, Koster, as crônicas de Abreu Medeiros (As Curiosidades Brasileiras, 1 1864) e os escritos de Afonso Arinos (Histórias e Paisagens, 19211.
15. "Negociantes paulistas de cavalos" desenho de J.B.Debret, ( $\mathrm{s} / \mathrm{d}$.) em Viagem Pito resca e História do Brasil; "Calçada do Lorena", desenho de Hercules Florence e "Tropeiros Paulistas no Rio de Janeiro", desenho de Chamberlain em Views and Cos tumes of Rio de Janeiro. Vários outros podem ser apreciados no livro de Jaelson Bitran Trindade, como por exemplo, "Limite da Província de São Paulo e de Curitiba. Ponte sobre o Rio Itararé", 1827 "Campeiros Proprietários de Tropas na Província do Rio Grande", s/d.; "Travessia do Rio Jaguaricatu, no Paraná", 1827, aquarelas de J.B. Debret, em Quarenta paisagen inéditas do Rio de Janeiro, São Paulo Paraná e Santa Catarina: "Pauvres Tropeiros de Minas", aquarela de J.B. Debret, 1823; "Escravo Negro conduzindo Tropas na Província do Rio Grande", aquarela de J.B.Debret, 1823 ; Litografia aquarelada de autor anônimo, registrando o tropeirismo na antiga vila de Sorocaba; "Pânico na Ponte" e "Distribuição de Sal às Tropas na Antiga Fazenda Fortaleza", desenhos de Bigg-Wither,c.1872 (Trindade 1992: 32-71). 
Colados aos documentos, chegando mesmo a confundir citações com suas falas, os historiadores dessas obras tratam de "interpretar" as descrições relativas ao cotidiano do tropeiro, adjetivando-as e buscando nelas as justificativas para a tese de integração nacional.

A introdução de Aluísio de Almeida à sua obra Vida e Morte do Tropeiro condensa exemplarmente essa postura: na coerente trajetória que apresenta, o Bandeirante e o Tropeiro são expressões do espírito paulista. Cronologicamente, ao bandeirante sucede o tropeiro e a este, as estradas de ferro a perpetuarem o progresso para os lados do sertão. A herança desbravadora do paulista daria à sua linhagem foros de nobreza - não é à toa que a qualificação de "monarca do sertão" ou "nobre paulista" aparece tão freqüentemente nesses estudos.

Taunay é, sem dúvida, quem concretiza essa imagem da paulistanidade, através de seus escritos e, sobretudo, das exposições históricas montadas no Museu Paulista. Para o historiador, a trajetória do tropeiro e sua função social no sertão têm suma importância e são qualificadas como parte de uma "marcha civilizatória":

"Não há como escurecer ou minguar a valia de sua missão progressista. Foram pioneiros da civilização social e de progresso econômico." (Taunay 1939:366).

Em suma, o tropeiro encarna a expressão mais pragmática possivel da história ideológica do alargamento das fronteiras nacionais.

A análise dos atributos composicionais e cromáticos e dos elementos temáticos indica a produção de uma imagem ruralizada para a São Paulo colonial. A composição e escala cromálica referenciadas pela pintura de paisagem e a introdução de motivos característicos da representação do campo são os elementos estruturadores dessa imagem de cidade em que fica sugerida uma coexistência sem conflitos entre núcleo urbano e meio rural, entre o passado colonial e o presente modernizado.

Na visão de Taunay, a obsolescência é o atributo que qualifica o passado da cidade, ou melhor, que dá o sentido de "antigo" em São Paulo.

Esse passado localiza-se, cronologicamente, em torno de 1860, período imediatamente anterior à instalação da estrada de ferro Santos-Jundiaí (1867) e ao primeiro pequeno surto de urbanização que São Paulo sofre na gestão de João Teodoro, Prefeito da capital da Província em 1872.

Marcos clássicos de mudança urbana de São Paulo, estas datas estão presentes em diversas e importantes obras referentes à história da cidade. Nos estudos de Taunay, este momento marca o ponto de partida para a arrancada do "progresso paulista". Em sua narrativa histórica, os fatores responsáveis pelo crescimento urbano encadeiam-se linear e coerentemente: de um lado, a ferrovia, representando a mudança tecnológica fundamental para a dinamização do comércio externo, na medida em que rompia o isolamento da capital serra acima com o porto de Santos; e de outro, a cultura do café que ocupa o território cada vez mais a sudoeste fazendo jus à tradição bandeirante.

Taunay não se atém aos conflitos de interesses entre os agentes sociais dessa história; a noção de progresso associada a valores tidos como intrin- 
secamente positivos o faz interpretar tensões e distúrbios no tecido social como naturais e inerentes à predestinada evolução da cidade, que aparece como fruto direto do sucesso da lavoura cafeeira ${ }^{16}$

Nessa construção histórica, a cidade atual surge como a resultante inelutável de uma conquista territorial, projetando, assim, um discurso que procura legitimar o poder político e econômico exercido pelas elites oligárquicas do café em São Paulo, justificado pelo "natural" espírito empreendedor do paulista.

No contexto cultural da década de 20, essas representações articulam-se a outros discursos e posturas estéticas quer modernistas, quer "tradicionalistas", que, apesar de se desenvolverem em circuitos paralelos e conotarem um aparente antagonismo, compartilham, como veremos a seguir, de um denominador comum - a questão do nacionalismo vinculada a uma determinada noção de cidade e de transformação urbana.

\section{A Pedagogia da Nação Paulista nas Imagens de Cidade}

O interesse de Taunay pela temática urbana não é casual. A cidade é um tema que concentra as representaçōes sobre a modernidade na década de 20, seja pelas transformações sociais que neste. momento já se configuravam, seja pela expectativa de mudanças radicais que a partir dela se esperava assistir.

As representações da modernidade entre os modernistas paulistas possuem muitos pontos de aproximação com o quadro internacional, o que poderia significar, à primeira vista, uma oposição irreconciliável com a imagem da cidade colonial encomendada por Taunay ${ }^{17}$.

Na cidade modernista o binômio indústria/multidão está no centro de imagens que relacionam a paisagem urbana a sentidos de desordem social, de caos, de perda de referenciais. A rua não é mais o lugar da sociabilidade harmoniosa e complementar, mas de uma ordem social em constante estado de tensão. Porém, esta mesma cidade caracterizada por tipos marginais como o boêmio, a prostituta e o bandido é atravessada por imagens que se fixam num ambiente ordenado pela tecnologia, pelo trabaho e pelo caráter impetuoso e audaz das figuras dos bandeirantes e seus sucessores (Fabris 1992).

Para além de uma convivência de visões contraditórias que o modernismo, pela sua própria natureza, permitia abraçar, sua condição utópica, ou seja, a noção de que era preciso inventar a modernidade no país, contamina de positividade ideológica o conjunto destas imagens-problema. A própria noção dinâmica de sociedade em estado de conflito permanente tem sua capacidade de questionamento reduzida perante a vinculação do pensamento intelectual a esquemas de interpretação de cunho evolucionișta, através dos quais era possível antever a modernidade desejada. Nesse sentido, é sintomático o investimento simbólico dos grupos, de algum modo vinculados ao modernismo, em projetos amplos que envolvem a questão da identidade cultural, especialmente no período pós-1924 (Ortiz 1989:32).
16. Esta postura fica clara quando, ao tratar da substituiçâo dá mão de obra escrava pela imigrante em seu livro Velbo São Paulo, Taunay simplifica $O$ processo e as fissuras sociais que essa mudança trouxe, ressalvando, apenas, como resultado, o aumento da produção cafeeira (Taunay 1954:7)

17. A percepção de um mundo em transiçāo, atravessado por crises de conotação apocalíptica, por visões de desintegração da ordem social são traços comuns de muitas das versões modernistas, especialmente na Europa, caracterizadas por Malcolm Bradbury. A sensibilidade em torno das mudanças vinha acoplada a uma profunda disposição para o experimentalismo formal que explora imagens de estranhamento, de efeitos de impacto, de descriação muitas vezes associadas ao mundo da tecnologia. Mesmo no contexto europeu o autor mostra, na segun da metade do século XIX, a sincronicidade destas visões desoladotas com noçôes de modernidade calcadas na confiança no progresso social, ou mesmo com associacões entre a postura naturalista e a felicidade social, possivel de ser alcançada pelo conhecimento racional e científico do mundo (Cf. Bradbury 1989). 
18. Carlos Zílio insiste na necessidade de relativizar as experiências de linguagem do modernismo brasileiro, que teve como uma de suas fontes o movimento francês conhecido como "Retorno a Ordem", caracterizado pela retomada de convenções e de hierarquias abolidas pelos modernistas históricos (Cf. Zilio 1992:19,20).

19. Em discurso proferido por ocasião da cerimônia de entrega de dois documentos anchietanos doados ao Museu Paulista em 1926, e publicado por Taunay, Paulo Prado, um dos patrocinadores da Semana de 22 , explicita o papel do Museu Histórico e de suas exposições, contrapondo-o aos tradicionais museus de arte, que considerava "Templo da Arte, perigosos e funestos", "... neste museu (Museu Paulista) só há, empalhados, bichos e borboletas. Uma $e$ outra manifestação artística, isolada torna-se sem perigo no ambiente naftalizado. Este museu é sobretudo o museu do nosso passado paulista, ainda palpitante, ainda com o calor e o interesse da yida de outrora. Seria próprio de uma criança, seria infantil ignorar que se passou antes de nós. É o desenvolvimento desse sentimento humano que se chama paixão histórica. Só no culto dessa paixão conseguiremos compreeender e realizar integralmente a I consciência, social, artística e intelectual do nosso Hoje, do nosso Profundo Hoje do poeta francês". (Prado 1926;379).
A partir destas balizas podemos pontuar não só oposições mas também confluências entre uma aparentemente tradicional série de pinturas de São Paulo no Museu Paulista e as representações modernistas.

De fato, as encomendas de Taunay trabalham com uma linguagem plástica absolutamente convencional em contraposição às preocupações formais presentes nos modernistas ${ }^{18}$. $O$ experimentalismo formal que poderia forjar uma arte autônoma, logo, especializada na exploração dos recursos de sua própria linguagem, terá que acompanhar os objetivos de projetos culturais que não podem abrir mão de certos níveis de convencionalismo. Para estes, as relações entre a vanguarda e a cultura de massas, ou entre as experiências nacionais e internacionais serão objeto de reflexão e um problema de síntese dificil (Meneses 1992).

No campo das artes plásticas, por exemplo, as semelhanças que podemos encontrar entre a série São Paulo Antigo e a cidade despovoada, marcada pela estaticidade e equilíbrio de composições ortogonais e de formas geométricas das telas de Tarsila do Amaral (Cattani 1992) mostram bem como era sutil o trânsito entre a radicalidade estética e o conservadorismo social e político quando se tratava de definir uma postura perante a modernidade. Para Taunay não existe nenhum traço de conflito na definição dos precursores da modernidade. A presença da oligarquia como protagonista do progresso urbano está implícita no elo que se estabelece entre campo e cidade. Para os modernistas, campo e cidade guardam significados opostos, o primeiro associado à barbárie e ao atraso, e a segunda ao progresso e à civilização (Fabris 1992).

A oposição campo/cidade, entretanto, não comprometia, mas tornava mais complexo o entendimento da oligarquia cafeeira como um dos agentes da modernização; mesmo porque é conhecido o suporte financeiro e social que protagonistas e eventos modernistas receberam destes grupos. As aproximaçōes de interesses podem ser percebidas no comportamento aparentemente contraditório de Tarsila do Amaral, uma das musas do modernismo, que na década de 40 executa, sob encomenda, quatro retratos a óleo de personalidades históricas para o Museu Paulista e seis retratos de convencionais para o Museu Republicano Convenção de ltu, anexo ao Museu Paulista, criado em 1923.

Entretanto, a cidade arcaica de Taunay não se apresenta como um modelo ideologicamente oposto à nova ordem, mas como o momento anterior à sua metamorfose em cidade industrial. O que merece ser destacado é uma visão apaziguada da sociedade, em evolução contínua, sem percalços sociais, logo, em contraposição a visões de ruptura, mesmo que afrouxadas pela expectativa de mudanças ${ }^{19}$.

As "reconstituições" do passado urbano colonial criam uma realidade, legitimada a partir do Museu, que serve de suporte para a crença, socialmente necessária, na capacidade de permanência da sociedade, logo, de sobrevivência de cada indivíduo. A função tranquilizadora destas representações se desdobra na habilidade em projetar no passado uma imagem compensatória de um mundo mergulhado em sucessivos momentos de crise e confronto (Horne 1984). 
Estas qualidades dos objetos transformados em monumentos celebrativos, como é o caso daqueles sob a gerência física e ideológica dos museus, não passaram de forma alguma desapercebidas na época. Em discurso do deputado Júlio Prestes à comitiva, que durante as comemorações do centenário da Independência inaugura os monumentos Cruzeiro Quinhentista, Padrão do Lorena e outros da estrada antiga da serra entre Santos e São Paulo, a perspectiva evolucionista, a conversão das tensões sociais em "vida intensa" e a reconstrução idealizadora do passado são abordados explicitamente:

\begin{abstract}
"Cada um destes monumentos rememora uma época, cada uma dessas épocas revela um estado da civilização, e todas elas, no seu conjunto, intimamente entrelaçadas como os elos de uma mesma corrente, representam a unidade, a seqüência, a marcha ascencional de nossa vida, qual se nos mostrassem, em diversas idades, fotogratias diferentes da mesma criatura.

Erguidos à margem desta estrada, como um culto ao passado, eles ligam entre si as idéias e a vida, o tempo e o espaço, explicando o presente. A vida intensa em que nos debatemos, a intelectualidade que formamos, o caminhar acelerado do nosso progresso sem comprometer a estabilidade de nossa civilização, tudo isso não seria suficientemente explicado sem o estudo de nossas origens e da marcha que fizemos através das idades e dos governos que se sucederam." (Prestes 1922:39).
\end{abstract}

Tradicionalmente, o tratamento serial permaneceu estranho aos objetos históricos colocados em exposição nos museus. A ausência de uma cobertura sistemática de tipologias documentais favoreceu uma compreensão autônoma do objeto de museu, suplementada pelo valor intrínseco de cada objeto como documento autêntico, ou seja, "relíquia" do passado, guardando um alto poder evocativo e merecedor de devoção religiosa.

Taunay, ao constituir séries documentais temáticas e tipológicas, pretendendo sintetizar visualmente uma versão histórica no espaço sacralizador do museu, estende a função celebrativa, inerente às exposições, à função pedagógica.

O desdobramento da exposição em instrumento educativo, finamente elaborado, evidencia a importância do museu como veículo de massa numa sociedade analfabeta e ainda não plenamente envolvida pelos meios de comunicação modernos. Temos aqui identificado o mesmo traço autoritário, marca da nossa modernidade, que predominou na produção cultural deste período, ou seja, a crença da intelectualidade na missão de conduzir os destinos da Nação (Pecault 1992).

Taunay assume o papel ativo do intelectual empenhado na construção e difusão de um passado capaz de fornecer os pressupostos para a formação de uma identidade cultural que tem como eixo a cidade e em torno da qual articulam-se representações do progresso e da modernidade.

A perspectiva é teleológica, pois a preservação histórica não significa que o passado deva ser tomado como modelo, mas que é a partir dele que se percebe e justifica o caráter imutável dos pontos de chegada. 


\section{BIBLIOGRAFIA}

AMARAL, Aracy. Artes Plásticas na Semana de 22. São Paulo, Perspectiva. 1982

BORGES, Maria Elízia. A Pintura na "Capital do Café": sua História e 1983 Evolução no Período da Primeira República. São Paulo, Fundação Escola de Sociologia e Política de São Paulo, (dissertação de Mestrado).

BOURDIEU, Pierre. A Economia das Trocas Simbólicas. 2 ed. São Paulo, 1987 Perspectiva.

BRADBURY, Malcolm e MCFARLANE (orgs.). Modernismo: guia geral 18901989 1930. São Paulo, Cia das Letras.

CATTANI, Iclea Borsa. O desejo de modernidade e as representações da 1992 cidade na pintura de Tarsila do Amaral. In: BULHÕES, Maria Amélia e KERN, Maria Lúcia Bastos(orgs.). A Semana de 22 e a emergência da modernidade no Brasil. Porto Alegre, Secretaria Municipal de Cultura, p.35-38.

CHIARELLI, Tadeu. Um Jeca nos vernissages: Monteiro Lobato e o Desejo de 1989 uma Arte Nacional no Brasil (1850- 1919). São Paulo, ECA/ USP, (dissertação de Mestrado).

DURAND, José Carlos. Arte, Privilégio e Distinção. São Paulo, Perspectiva. 1989

FABRIS, Annateresa. O espetáculo da Rua: Imagens da cidade no primeiro 1992 modernismo. In: BULHÕES, Maria Amélia e KERN, Maria Lúcia Bastos (orgs.). A Semana de 22 e a emergência da modernidade no Brasil. Porto Alegre, Secretaria Municipal de Cultura, p.31-34.

FREIRE, Laudelino. Um século de pintura: 1816-1916. Rio de Janeiro, Tip. 1916 Rohe.

HORNE, Donald. The Great Museum: the re-presentation of history. London 1984 and Sidney, Pluto.

IHERING, Hermann von. História do Monumento do Ipiranga e do Museu 1895 Paulista. Revista do Museu Paulista, v.1, p.9-31.

LEE, Francis Melvin. Henrique Bernardelli. São Paulo, FAU/USP, 1991 (dissertação de Graduação), (ms.). 
LEMOS, Carlos A.C. Alvenaria Burguesa: breve bistória da arquitetura resi 1985 dencial de tijolos em São Paulo a partir do ciclo econômico liderado pelo café. São Paulo, Nobel.

LEMOS, Carlos A.C. À procura da memória nacional. Memória. São 1993 Paulo, 17:17-24, jan./fev./mar.

LIMA, Solange Ferraz de. O Circuito Social da Fotografia - estudo de caso II 1991 In: FABRIS, Annateresa (org.). Fotografia, Usos e Funções no século XIX. São Paulo, Edusp, p.59-82.

MENESES, Ulpiano T. Bezerra de. Apresentação. In: AMARAL, Aracy. 1992 Artes Plásticas na Semana de 22. São Paulo, BOVESPA E BM\&F, p.7-11.

NEWHALL, Beaumont. The history of photography. New York, MOMA.

1982

ORTIZ, Renato. A moderna tradição brasileira. São Paulo, Brasiliense.

1989

PECAUT, Daniel. Les intellectuels, la nation et la démocratie au Brésil In: BU1992 LHÕES, Maria Amélia e KERN, Maria Lúcia Bastos (orgs.). A Semana de 22 e a emergência da modernidade no Brasil. Porto Alegre, Secretaria Municipal de Cultura, p.10-18.

PRADO, Paulo. Dois Documentos Anchietanos Inéditos. In: TAUNAY, Affonso 1926 de E. Antigos Aspectos Paulistas. São Paulo, s.c.p. .

PRESTES, Júlio. Comemorações do Centenário da Independência. Correio 1922 Paulistano. São Paulo, 7 set., p.39.

SÃO PAULO. Leis, Decretos, etc. Decreto n.249 de 26 de julho de 1894. In: 1913 Coleção das Leis e Decretos do Estado de S.Paulo de 18931894. São Paulo, Tip. do Diário Oficial, v.1, p.204.

SÃO PAULO. São Paulo em Três Tempos: Álbum Comparativo da Cidade de 1982 São Paulo (1862-1887-1914). São Paulo, Casa Civil/Imprensa Oficial do Estado S.A./ Secretaria da Cultura/ Arquivo do Estado.

SEVCENKO, Nicolau. Orfeu Extático na Metrópole - São Paulo, Sociedade e 1992 Cultura nos Frementes anos 20. São Paulo, Cia das Letras.

TARASANTCHI, Ruth S. A Vida Silenciosa na Pintura de Pedro Alexandrino. 1981 São Paulo, ECA/USP, (dissertação de Mestrado). 
TAUBERT, P. O fim e a disposição de um Museu Botânico. Revista do Museu 1895

Paulista, v.1,p.161-164.

TAUNAY, Affonso de E. - A Missão Francesa. São Paulo, Instituto Histórico e 1912

Geográfico Brasileiro/Jornal do Comércio.

TAUNAY, Affonso de E. Guia da Seção Histórica do Museu Paulista. São 1937a Paulo, Imprensa Oficial do Estado.

TAUNAY, Affonso de E. A propósito do curso de História da Civilização 1937b Brasileira na Faculdade de Filosofia, Ciências e Letras Anuário da Faculdade de Filosofia, Ciências e Letras da Universidade de Sâo Paulo - 1934-35. São Paulo, Empresa Gráfica da Revista dos Tribunais, p. 122-130.

TAUNAY, Affonso de E. História do Café. Rio de Janeiro, Departamento do 1939 Café, v.4.

TAUNAY, Affonso de E. A mais velha iconografia brasileira do café. Mensário 1944 do Jornal do Comércio. tomo 28, v.2, p. 385-389.

TAUNAY, Affonso de E. A Propósito do Próximo Cincoentenário do Museu 1945a Paulista (1895-1945). Mensário do Jornal do Comércio. Rio de Janeiro, 31(1):495-500, julho a set.

TAUNAY, Affonso de E. As feiras de Sorocaba e sua iconografia. Mensário do 1945b . Jornal do Comércio. tomo 29, v. 1, p. 103-105.

TAUNAY, Affonso de E. Iconografia paulista vetustíssima. Anais do 1949 Museu Paulista. tomo 13, p.30-45.

TAUNAY, Affonso de E. Velho São Paulo. São Paulo, Melhoramentos, 1954

TOLEDO, Benedito Lima de. São Paulo: três cidades em um século. São Paulo, 1983 Duas Cidades.

TRINDADE, Jaelson Bitran. Tropeiros. São Paulo, Editoração Publicações e 1992 Comunicações Ltda.

WALSH, Kevin. The representation of the past: museums and beritage in the 1992 post-modern world. London, Routledge.

ZÍLIO, Carlos. O artista modernista enquanto intelectual. In: BULHÕES, Maria 1992 Amélia e KERN, Maria Lúcia Bastos (orgs.). A Semana de 22 e a emergência da modernidade no Brasil. Porto Alegre, Secretaria Municipal de Cultura, p.19-20. 


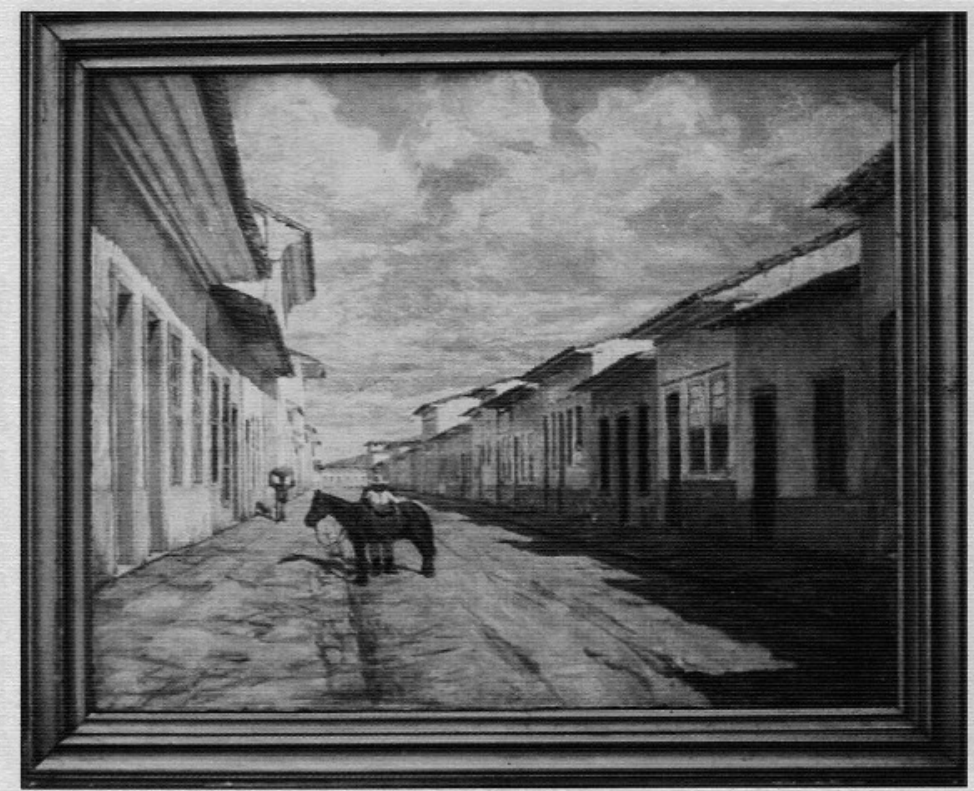

FIG. 1

"Rua das Flores" - Henrique Manzo (1896-1982)

Óleo sobre tela / a.c.i.e. H. Manzo / sem data / $65,0 \times 81,5 \mathrm{~cm}$

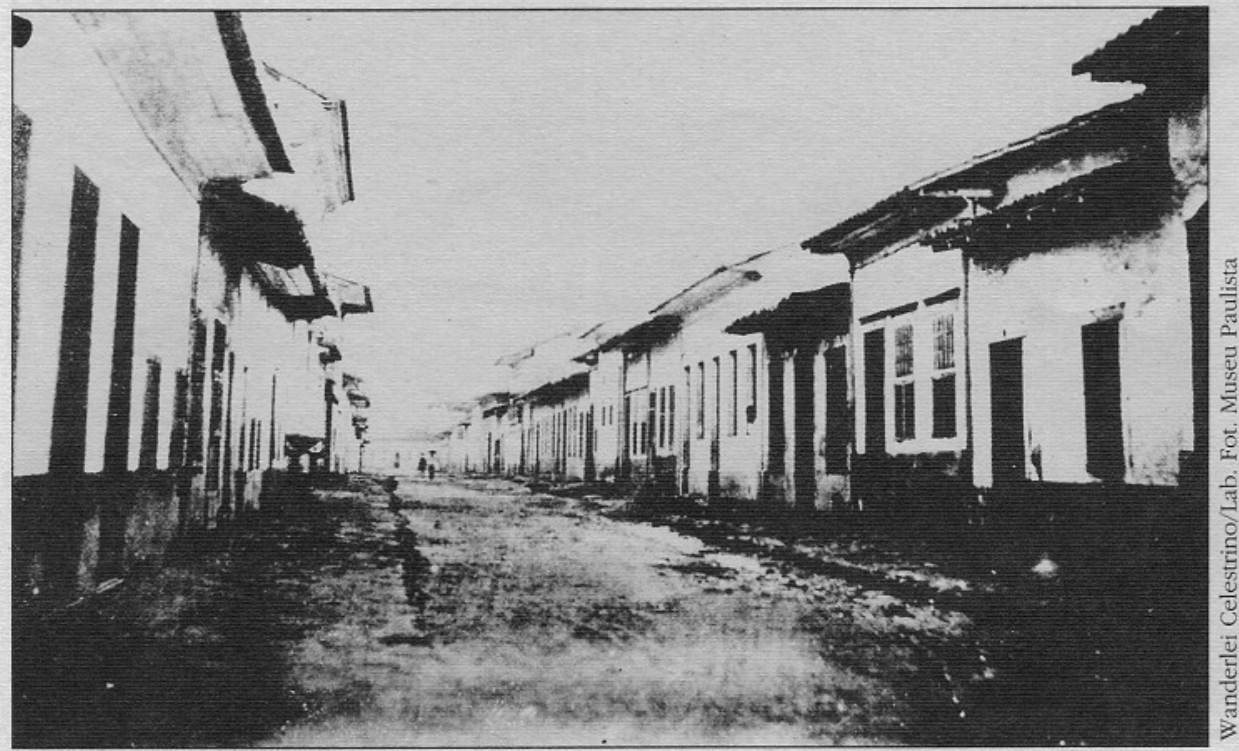

Reprodução de "Rua das Flores" - Militão Augusto de Azevedo (autoria atribuída) 1860 / 14,2 × 20,8 cm / São Paulo Antigo 1860 / Museu Paulista. 
FIG. 2

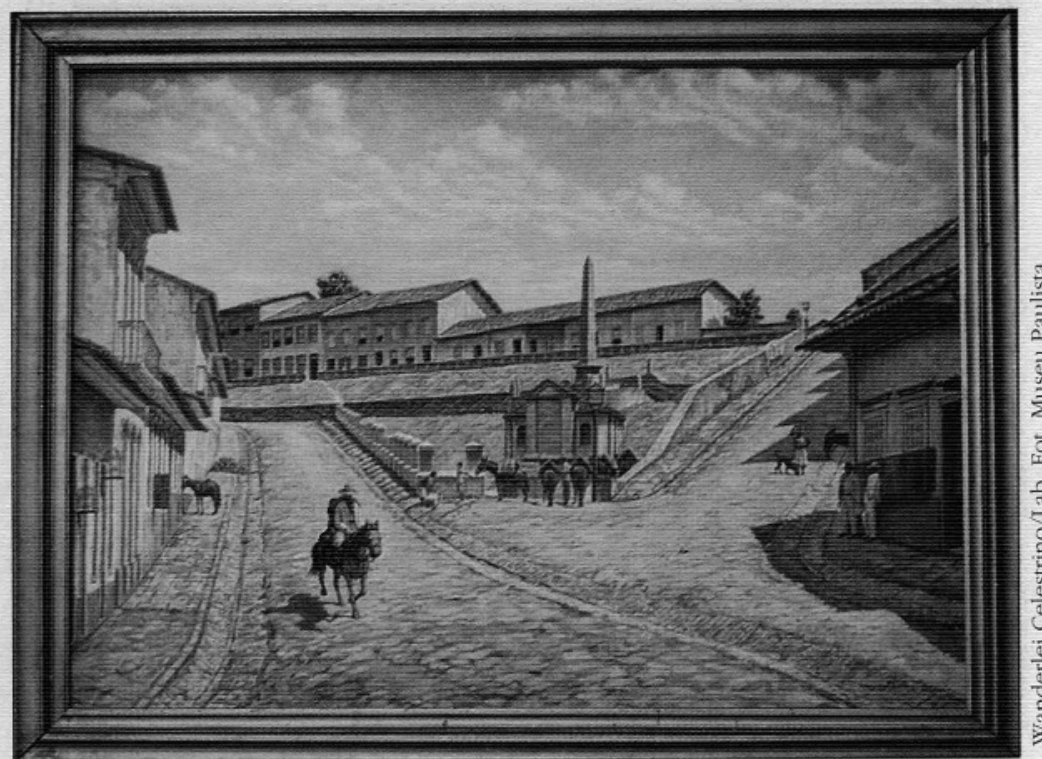

"Piques, 1860" - Henrique Manzo (1896-1982)

Óleo sobre tela / a.c.d. H. Manzo / São Paulo 1945 / 73,3 x 101,4 cm

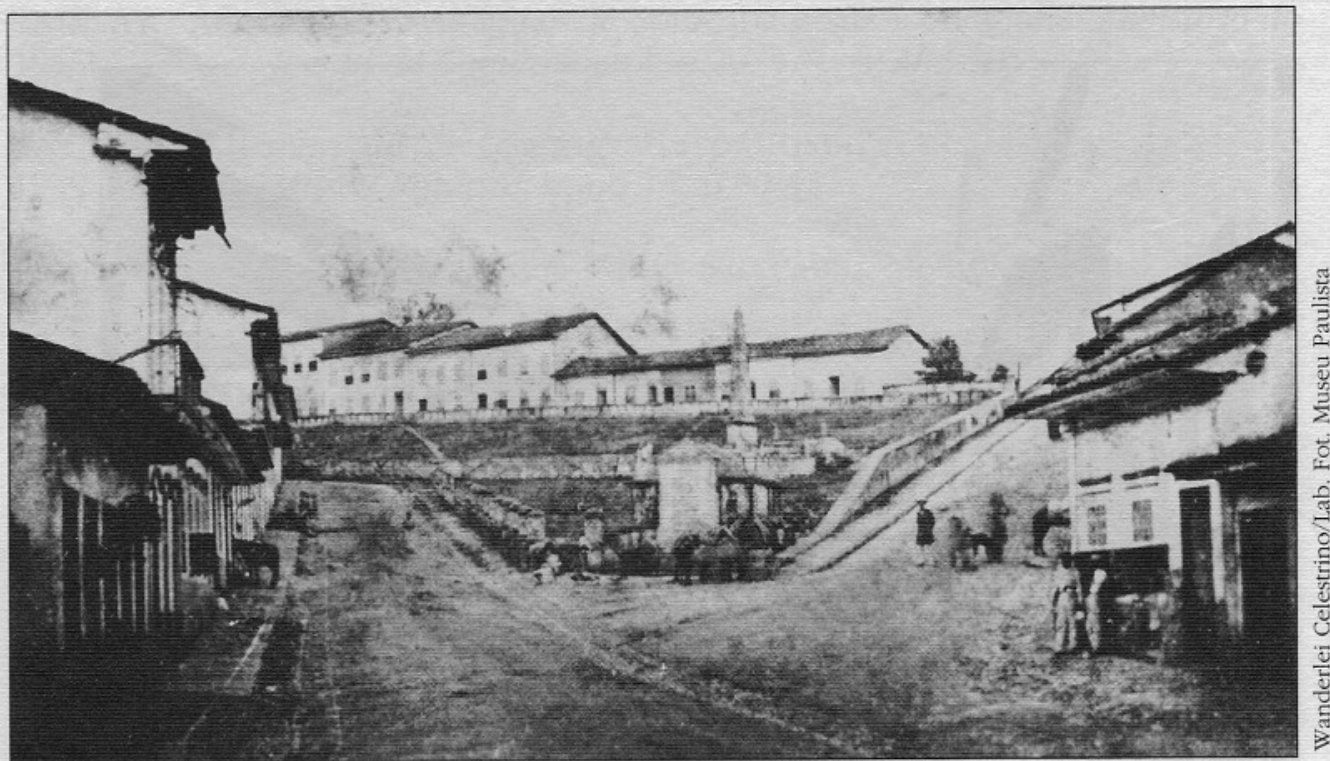

Reprodução de "Paredão de Piques, Ladeiras da Consolação e da Rua do Palha" Militão Augusto Azevedo 1862 / 12,9 × 21,8 cm / Azevedo, Militão A. Álbum Comparativo da Cidade de São Paulo. 1862-1887 / São Paulo, photografia Americana, sem data, página 48. / Museu Paulista 


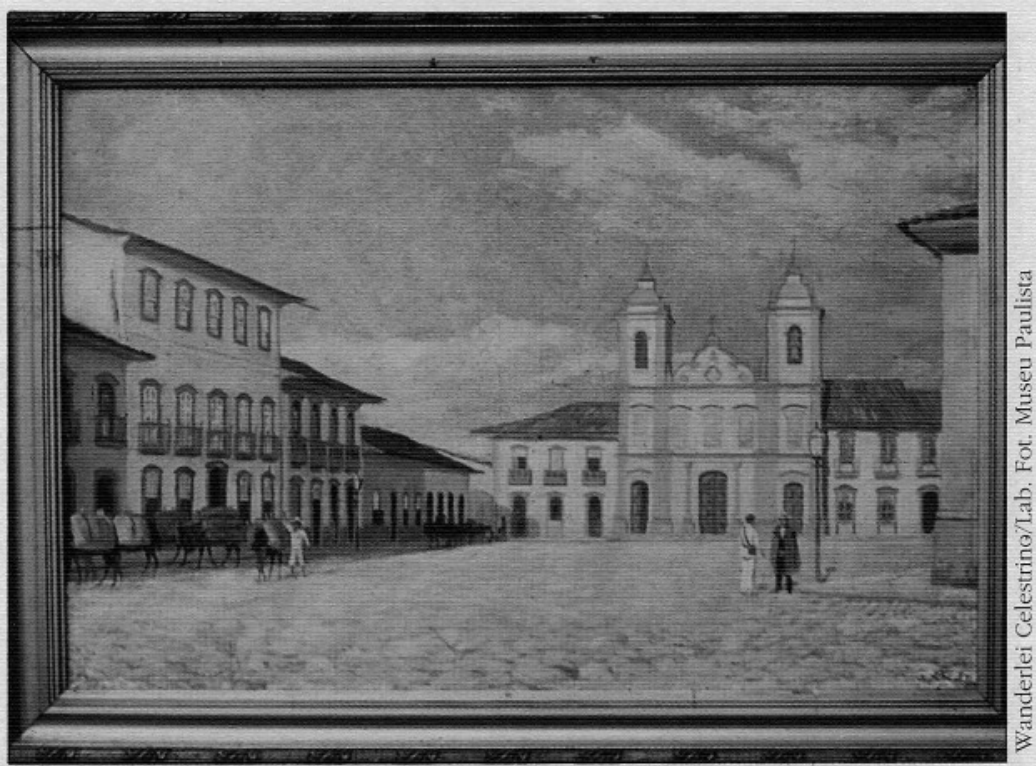

FIG. 3

"Pátio da Sé e lgreja de São Pedro" - José Wasth Rodrigues (1891-1957)

Óleo sobre tela / a.c.i.d. J.W.R. $1919 / 54 \times 81 \mathrm{~cm}$

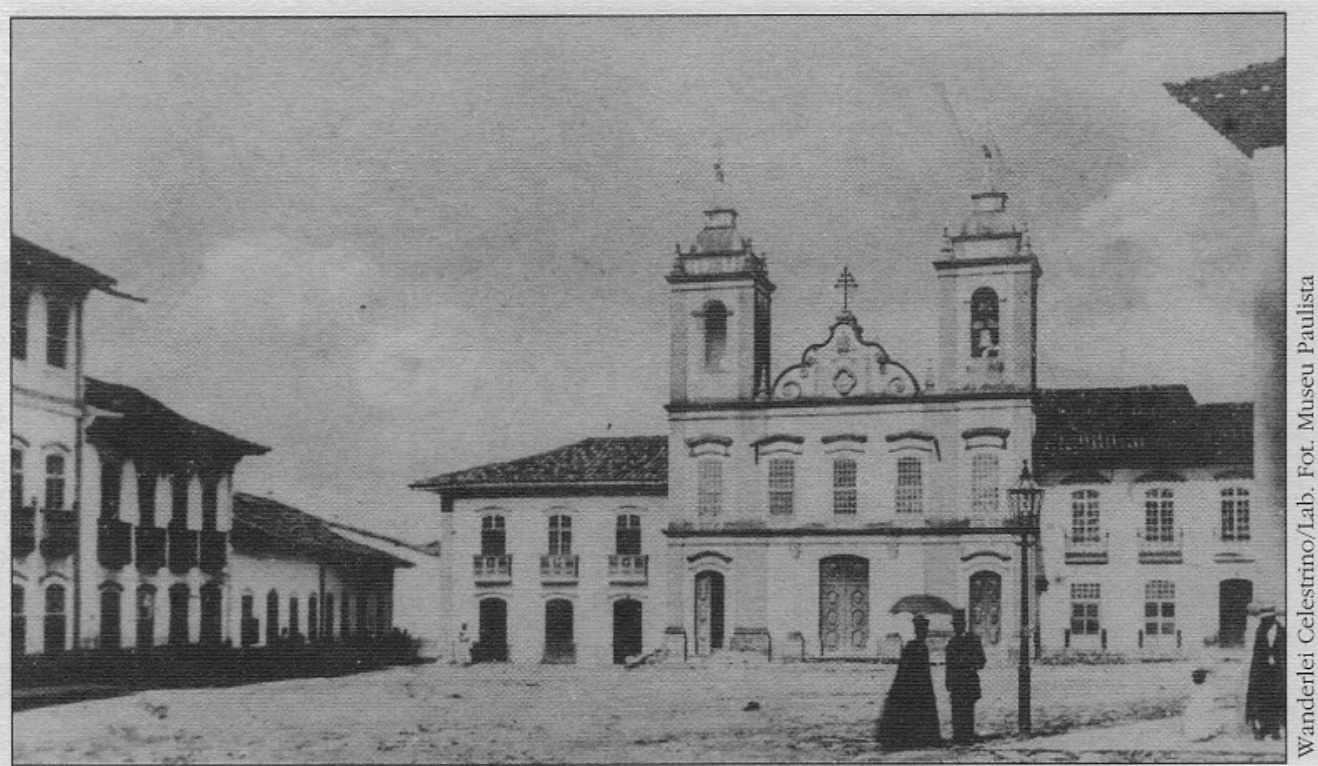

Reprodução de "Largo da Sé e Igreja de São Pedro" - Militão Augusto Azevedo (autoria atribuída) 1862 / $18 \times 24 \mathrm{~cm} /$ Álbum Comparativo da Cidade de São Paulo, organizado pelo

Sr. Dr. Washington Luis Pereira de Souza. Prefeito Municipal / sem data / cerca de 1916 / Biblioteca Municipal Mário de Andrade. 
FIG. 4

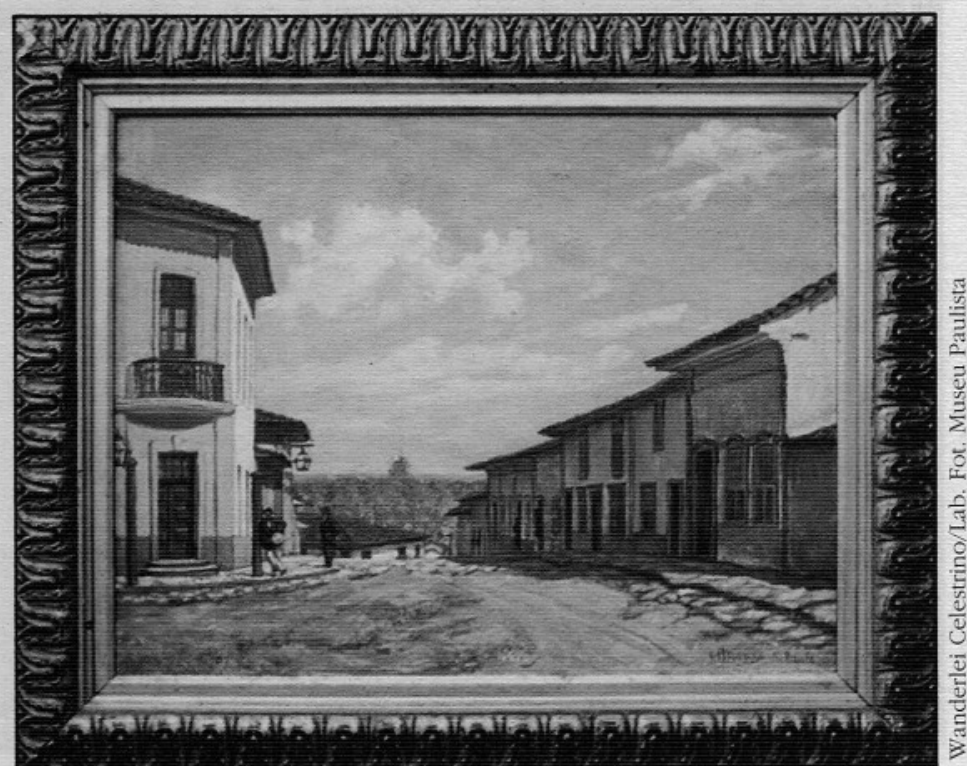

"Largo do Ouvidor em 1858" - Henrique Manzo (1896-1982) Óleo sobre tela / a.c.i.d. H. Manzo / São Paulo sem data / $35,6 \times 45,5 \mathrm{~cm}$

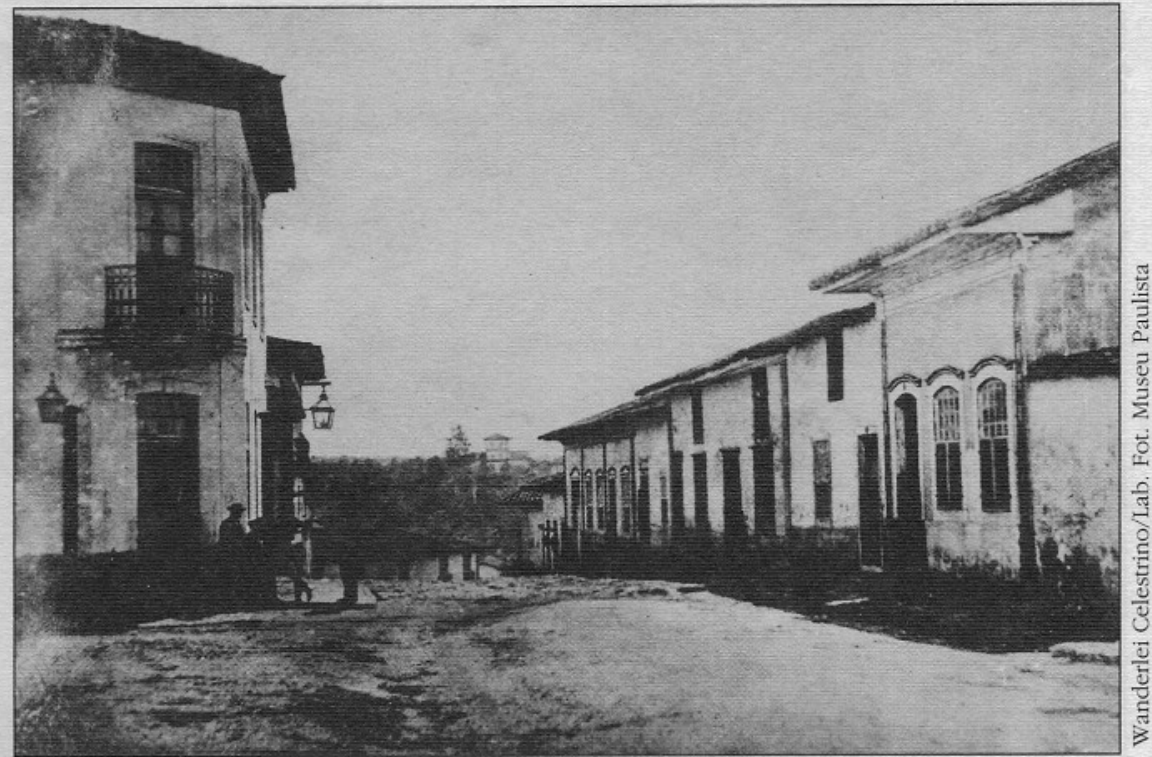

Reprodução de "Ladeira do Meio (do Ouvidor)" - Militão Augusto de Azevedo (autoria atribuída) $1860 / 14,0 \times 20,8 \mathrm{~cm} /$ São Paulo Antigo. 1860 / Museu Paulista. 


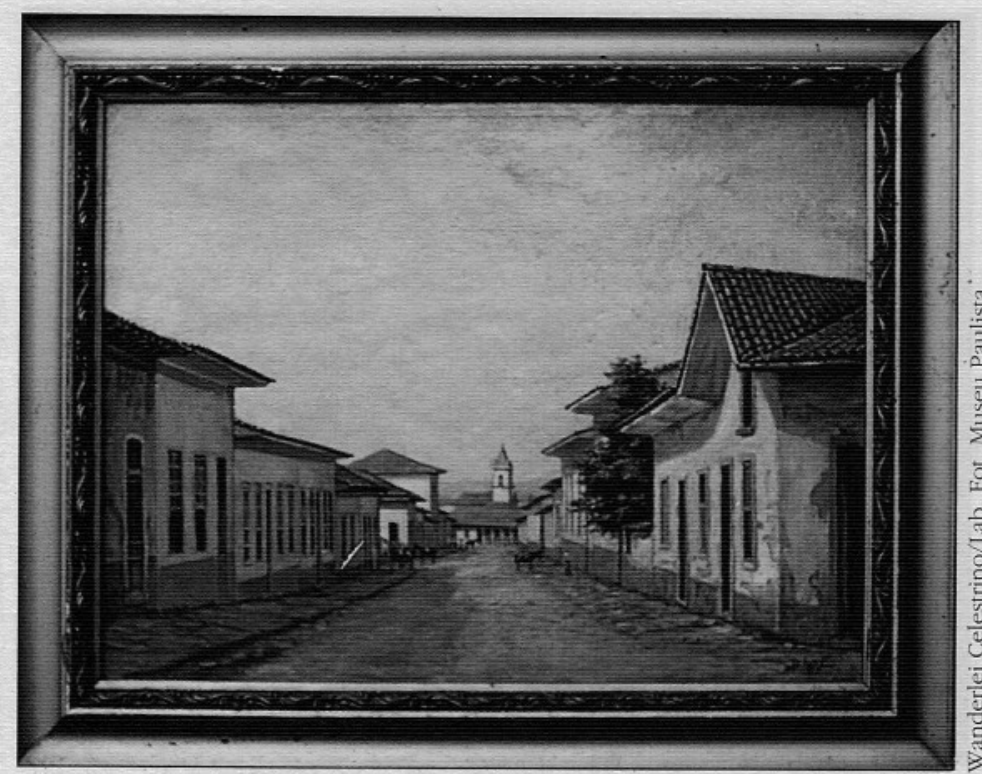

FIG. 5

"Rua da Cruz Preta em 1858" - Benedito Calixto de Jesus (1 853-1927)

Óleo sobre tela / a.c.i.d. B. Calixto / sem data / 50,0 ×65,0 cm

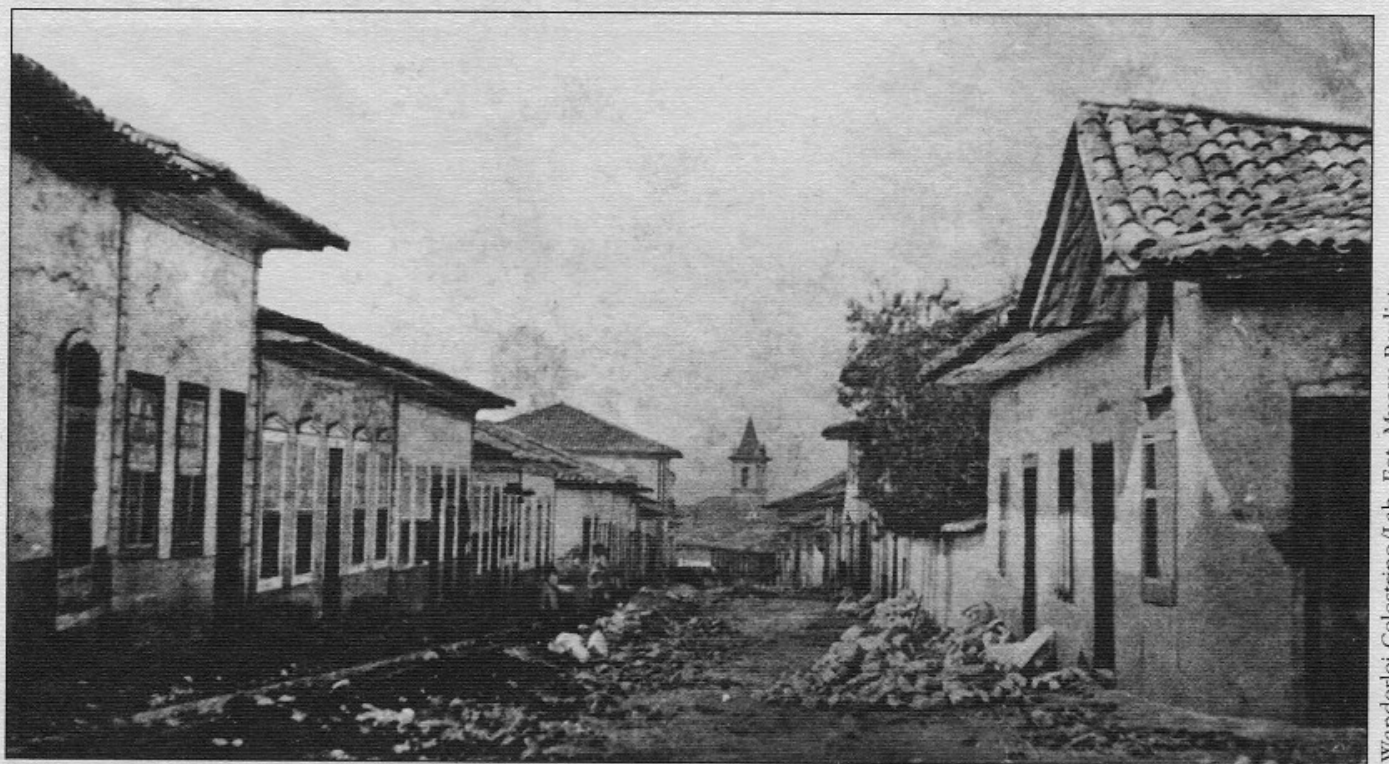

Reprodução de "Rua da Cruz Preta" - Militão Augusto Azevedo 1862 / 11,8 x 20,5 cm /

Azevedo, Militão A. Album Comparativo da Cidade de São Paulo. 1862-1887 /

São Paulo, photographia Americana, sem data, página 26 / Museu Paulista 
FIG. 6

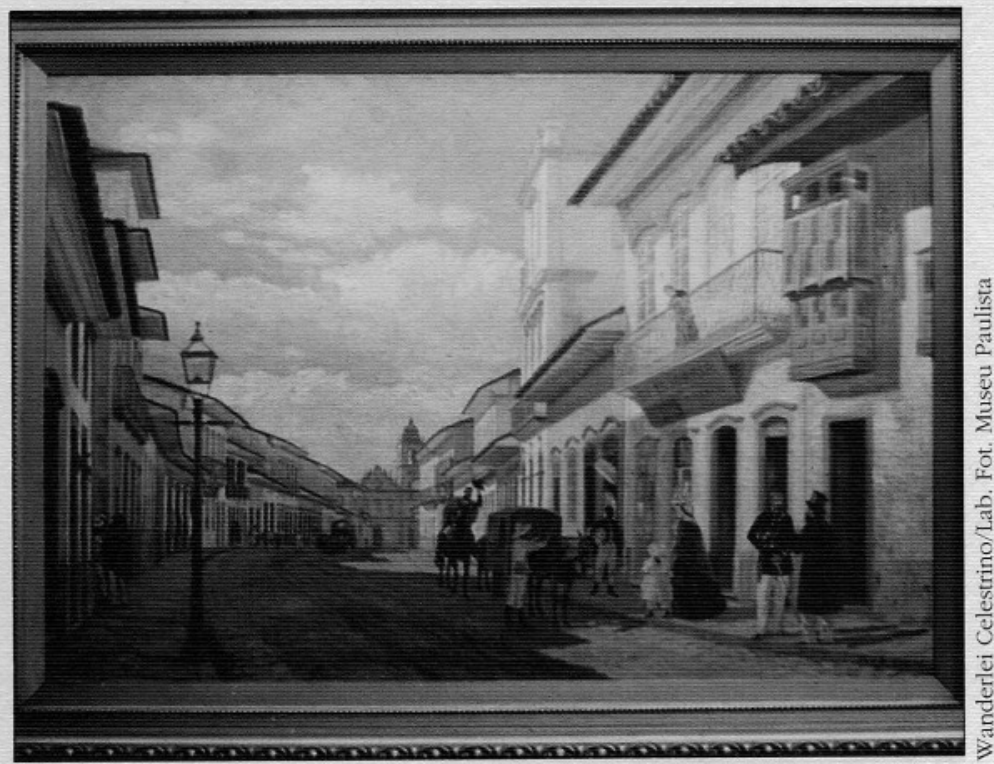

"Rua do Rosário em 1858" - José Wasth Rodrigues (1891-1957)

Óleo sobre tela / a.c.i.d. J.W.R. 1920/110 × $160 \mathrm{~cm}$

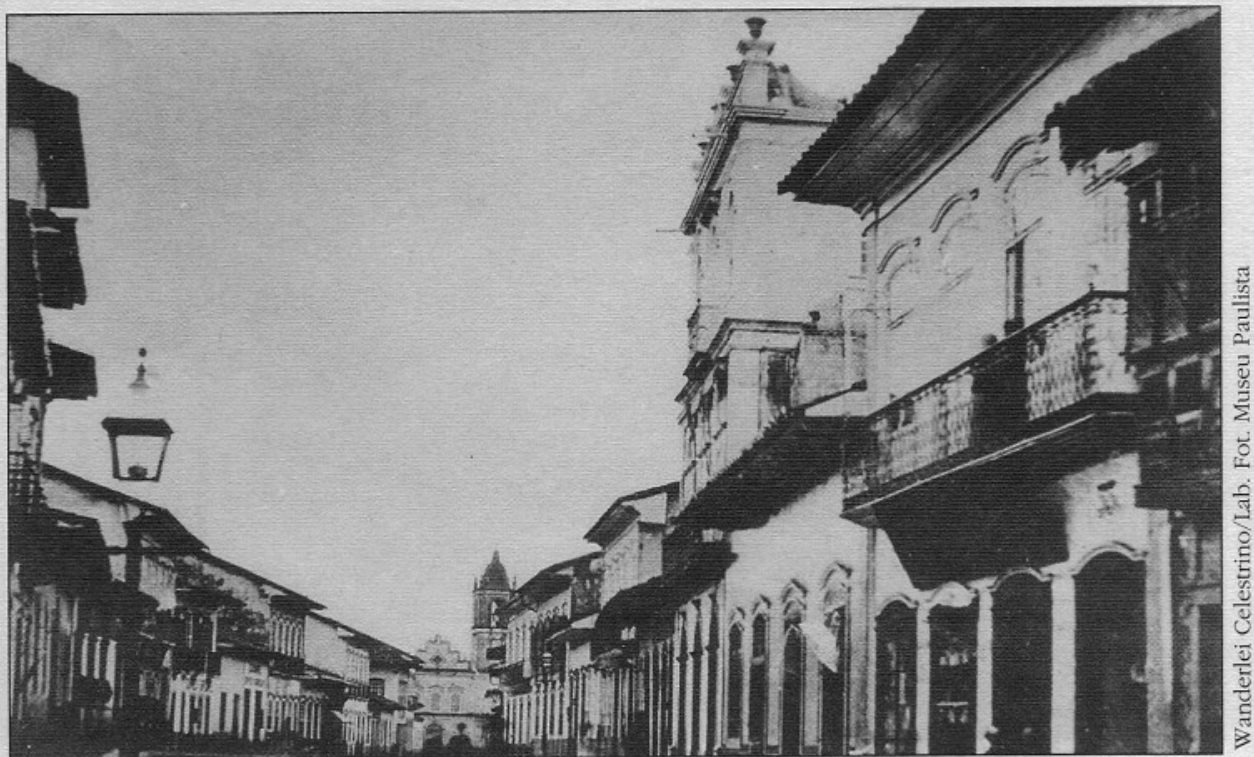

Reprodução de "Rua do Rosário. (lado da lgreja)" - Militão Augusto Azevedo 1862 / $14,1 \times 22,0 \mathrm{~cm} /$ Azevedo, Militão A. Álbum Comparativo da Cidade de São Paulo. 1862-1887 / São Paulo, photographia Americana, sem data, página 20 / Museu Paulista 


\section{BIOGRAFIAS DOS PINTORES E CATALOGAÇÃO DAS OBRAS CITADAS}

\section{Miyoko Makino \\ MP/Universidade de São Paulo}

Benedito Calixto de Jesus nasceu em Itanhaém, SP, em 1853 e faleceu na Capital, em 1927. Estudou em Paris, na Académie Julien e teve como mestres Gustave Boulanger, Lefebvre e Robert Fleury. Seu período de estadia na europa foi de 1881 a 1885 . Salienta-se em suas obras um gosto acentuado pelo tema regionalista. Pintou marinhas e paisagens. Seu traço característico encontra-se no amor às tradições populares, cívicas e religiosas, tendo se dedicado, nos últimos anos de sua vida, à pintura histórica, de costumes regionais e temas religiosos. Escreveu memórias históricas sobre São Paulo, Santos, Itanhaém e litoral santista, além de contos como o intitulado "Costumes de minha terra".

José Wasth Rodrigues era natural de São:Paulo, tendo nascido em 1891, faleceu em 1957, no Rio de Janeiro. Realizou estudos, durante dois anos, com Oscar Pereira da Silva. Foi não somente pintor, mas também historiador e especialista em mobiliário, armaria e heráldica. Destacou-se, ainda jovem, em artes plásticas. Em 1910, recebeu do governo paụlista prêmio de viagem à Europa. Frequentou em Paris a Académie Julien e a École de BeauxArts, tendo por mestres Jean Paul Laurens, Nandi e Lucien Simon. Expôs no Salão de Paris em 1914, e antes do início da I Guerra, regressou ao Brasil. Dois anos mais tarde fundou, em São Paulo, um curso de desenho e pintura, juntamente com Elponse e Zadig. Recebeu sua primeira medalha de ouro, no Salão Paulista de 1933 e primeiro prêmio de pintura em 1934. Em suas viagens por Minas Gerais, Bahia, Pernambuco e Rio de Janeiro registrou em óleos, aquarelas e desenhos, principalmente bicos-de-pena, velhos solares, igrejas e monumentos dessas regiões. Prestou colaboração ao Departamento do Patrimônio Histórico e Artístico Nacional, participando do Conselho consultivo e executando obras artísticas. Publicou as seguintes obras: Documentário arquitetônico relativo à antiga construção civil no Brasil, em oito volumes, amplamente ilustrados; Móveis antigos de Minas Gerais; A casa da moradia do Brasil antigo; além de desenhos e aquarelas do livro Uniformes do Exército Brasileiro. Jonas de Barros era natural de ltu (SP). Faleceu em agosto de 1939, em São Paulo. Em 1895 já participava de exposições na Casa Garraux e, em 1901, expôs "Rinha de Galos" e, em 1908, o esboço da pintura histórica "A Convenção de ltu, 1873", cujo quadro a óleo pertence ao acervo deste Museu e encontra-se exposto no Museu Republicano "Convenção de ltu", na cidade de Itu (SP). Nesse mesmo ano de 1908, recebeu medalha de Ouro na exposição da Escola Nacional de Belas Artes. Em 1902, realizou exposição individual com trinta obras, na Galeria Castelões. Convidado por Affonso de Taunay executou retratos de convencionais de ltu e vistas da cidade de São Paulo. Por ocasião de seu falecimento, estava com obras expostas na sede da Associção dos Funcionários Públicos do Estado de São Paulo, à rua São Bento. Seus trabalhos abordaram a paisagem, pintura de gênero, costumes e retratos. 
Henrique Manzo nasceu em São Bernardo do Campo (SP), em 1896, e seu falecimento ocorreu, na Capital, em 1982. Matriculou-se, em 1913, no Liceu de Artes e Ofícios de São Paulo, no Curso de Artes Plásticas. Expôs em 1917, obtendo medalha de bronze. Passou um ano no Rio de Janeiro, expondo no Salão Nacional de Belas Artes, em 1918. Regressando a São Paulo, continuou a enviar suas pinturas ao Saläo Nacional, obtendo duas premiações. Sua primeira individual deu-se em 1938, em São Paulo. Nas exposições do Salão Paulista de Belas Artes conseguiu algumas medalhas. Em 1964, recebeu uma pequena medalha de ouro e, nesse mesmo ano, inaugurou em sua propriedade, perto do Morro do Jaraguá, a Galeria Narcisa. Foi homenageado em 1978. Dedicou-se a retratos, paisagens e pinturas de gênero. Convidado por Affonso de Taunay, realizou muitas vistas da cidade de São Paulo e de cidades paulistas, cenas de fazendas, retratos e cenas alegóricas, a partir de fotografias, gravuras, aquarelas e informaçōes históricas. Foi pintor e restaurador do Museu Paulista na gestão de Affonso de Taunay.

Bertha Adams Worms nasceu na região de Lorena, França, no ano de 1968 e faleceu em São Paulo em 1932. Realizou seus estudos na Académie Julien, em Paris, tendo sido, entre outros, seus mestres Jules Lefvre, Gustave Boulange, Fleury e Benjamin Constant. Dedidou-se ao retrato, pintura de gênero, natureza morta, ocupando-se muito pouco da paisagem. Teve suas obras expostas no Salon de Paris. Realizou coletivas e individuais em São Paulo e Rio de Janeiro. Participou da Exposição Geral de 1922. 


\section{CATÁLOGO DAS OBRAS}

“Antiga Estação da Luz". Benedito Calixto de Jesus (1853-1927). Óleo sobre tela. a.c.i.d. Benedito Calixto s/d. $50,0 \times 60,5 \mathrm{~cm}$.

"Rua do Rosário em 1858". José Wasth Rodrigues (1891-1957). Óleo sobre tela. a.c.i.d. J.W.R. $1920.110 \times 160 \mathrm{~cm}$.

"Rua Direita e Largo de São Pedro, 1858". José Wasth Rodrigues (18911957). Óleo sobre tela. a.c.i.d. J.W.R. 1922. $86 \times 65 \mathrm{~cm}$.

"Páteo da Sé em 1862". José Wasth Rodrigues (1891-1957). Óleo sobre tela. a.c.i.e. J.W.R. 1918 . $30,4 \times 36,3 \mathrm{~cm}$.

"Trecho Final da Antiga Rua do Rosário, 1858". José Wasth Rodrigues (18911957). Óleo sobre tela. a.c.i.d. J.W.R. 1919. 44x61,5cm.

“Aspecto da Rua do Rosário à Noite em 1862'.José Wasth Rodrigues (18911957). Aquarela. a.c.i.e. J.W.R. 11-1917. 38,7x33,7cm.

"Rua Direita". José Wasth Rodrigues (1891-1957). Bico de Pena. a.c..i.d.J.W.R. 1918. $33,7 \times 39,7 \mathrm{~cm}$.

"Páteo da Sé e Igreja de São Pedro".José Wasth Rodrigues (1891-1957). Óleo sobre tela. a.c.i.d.J.W.R. $1919.54 \times 81 \mathrm{~cm}$.

"Ruas do Carmo e Boa Morte, 1860". Jonas de Barros (? - 1939). Óleo sobre tela. a.c.i.d. J. Barros s/d. 44,5x62,5cm.

"Igreja da Boa Morte, 1860'. Henrique Manzo (1896-1982). Óleo sobre tela. a.c.i.e. H. Manzo s/d. $65,0 \times 81,5 \mathrm{~cm}$.

"Largo do Ouvidor em 1858". Henrique Manzo (1896-1982). Óleo sobre tela. a.c.i.d. H. Manzo S. Paulo s/d. 35,6x45,5,cm.

"Convento da Luz, em 1860". Henrique Manzo (1896-1982). Óleo sobre tela. a.c.i.e. H. Manzo s/d. $44,4 \times 81,0 \mathrm{~cm}$.

"Rua das Flores". Henrique Manzo (1896-1982). Óleo sobre tela. a.c.i.e. H. Manzo s/d.65,0x81,5cm

"Piques, 1860". Henrique Manzo (1896-1982). Óleo sobre tela. a.c.i.d. Henrique Manzo - São Paulo 1945. 73,3×101,4cm.

"Rua da Tabatinguera, 1860". Berthe A. Worms (1868-1937). Óleo sobre tela. a.c.i.d. B. Worms s/d. $52,0 \times 60,5 \mathrm{~cm}$. 
"Ladeira do Colégio, 1860". Benedito Calixto de Jesus (1853-1927). Óleo sobre tela. a.c.i.d. B. Calixto s/d. 50,2x65,0cm.

"Paço Municipal, Forum, Cadeia de São Paulo em 1862". Benedito Calixto de Jesus (1853-1927). Óleo sobre tela. a.c.i.d. B. Calixto s/d. $49,0 \times 70,5 \mathrm{~cm}$.

"Largo e Matriz o Brás em 1862". Benedito Calixto de Jesus (1853-1982). Óleo sobre tela. a.c.i.d. B. Calixto s/d. 49,7x64,1cm.

"Inundação da Várzea do Carmo em 1892". Benedito Calixto de Jesus (1853-1927). Óleo sobre tela. a s/d. $125 \times 400 \mathrm{~cm}$.

"Rua da Quitanda, 1858". Benedito Calixto de Jesus (1853-1982). Óleo sobre tela. a.c.i.d. B. Calixto s/d. 50,4x60,0cm.

"Rua da Constituição, 1862". Benedito Calixto de Jesus (1853-1927). Óleo sobre tela. a.c.i.d. B. Calixto s/d. 49,2x59,5cm.

"Rua da Cruz Preta em 1858. Benedito Calixto de Jesus (1853-1927).Óleo sobre tela. a.c.i.d. B. Calixto s/d. 50,0x65,0cm.

"Largo de São Bento, 1880". Nicola Petrilli. Óleo sobre tela. a.c.i.d. N. Petrilli s/d. $64,3 \times 74,9 \mathrm{~cm}$. 
Eclecticism in Brazilian architecture: a scenery for modernization.

Annateresa Fabris

The author enhances the social and cultural meaning of Eclecticism, beyond the domain of Architecture and the level of stylistic phenomena. This frame of reference allows her to understand in a historical key its scenographical tendencies and the taste for magnificence, expressiveness and monumentality, as well as its links with the past. Some specific features of Brazilian Eclecticism are then described, as its anti-colonialistic bias. Neoclassical movement is included as a late manifestation of Eclecticism which survives until the establishment of a new kind of relationship with modernity - mediated by technology.

UNITERMS: Eclecticism. Eclecticism and architecture (Brazil). Eclecticism, modernity, modernization.

An. MP, NS 1: pg. 131, 1993.

São Paulo antigo, uma encomenda da modernidade : as fotografias de Militão nas pinturas do Museu Paulista.

Solange Ferraz de Lima e Vânia Carneiro de Carvalho

Por ocasião das comemorações do centenário da Independência do Brasil em 1922, o então diretor do Museu Paulista, Affonso de Escragnole Taunay, empenhousse na montagem de exposiç̃os voltadas para a reconstituição arcaizante do passado urbano de São Paulo. Parte desse projeto consistiv em encomendas de pinturas realizadas a partir de matrizes fotográficas do século passado. O presente estudo discute as estratégias visuais presentes na transcodificaçăo de objetos iconográficos de natureza diversa no ámbito do espaço celebrativo do Museu e seus desdobramentos ideológicos, implícitos nas ações de caráter nacionalista, 'educacional e preservacionista.

UNITERMOS: Iconologia. Pintura e modelos fotográficos. História do imaginário (São Paulo "Colonial"). História de coleçôes (Museu Paulista, décáda de 20).

An. MP. NS 1; pg. 147, 1993.

Ancient São Paulo, modernity's commission: Militão's photographs as models for oil paintings at the Museu Paulista.

Solange Ferraz de Lima e Vânia Carneiro de Carvalho

The centennial commemoration of Brazil's Independence in 1922 offered the director of the Museu Paulista at that time, Affonso de Escragnole Taunay, the opportunity to organize public exhibitions dedicated to an archaizing recreation of São Paulo's urban past. Part of this commemoration resulted in commissioning well known artists to produce oil canvasses from 19th. - century photographic sources. The present study examines the visual strategies in the translation of dissimilar iconographic media, considered within the Museum's celebrative functions, and the ideological implications in their nationalistic, pedagogic and conservational aims.

UNITERMS: Iconology. Painting and photographic models. History of the imaginaire ("Colonial" São Paulo). History of collections (Museu Paulista, 1920's)

An. MP. NS 1: pg. 147, 1993.

Sintomas do modo de vida burguês no vale do Paraiba, séc. XIX. Fazenda São Fernando, Vassouras RJ (Exploraçăo arqueológica e museológica).

Tânia Andrade Lima, Maria Cristina Oliveira Bruno e Marta Ferreira Reis da Fonseca

No âmbito de um projeto voltado para investigar arqueologicamente o surgimento do modo de vida burguês, que antecede a instalação da burquesia propriamente dita no país, vêm sendo pesquisadas unidades de produção de café implantadas em meados do século passado no Vale do Parába Fluminense. A Fazenda São Fernando, situada no município de Vassouras RJ, na condição de um dos mais notáveis exemplos do processo de expansão, apogeu e decadência desta monocultura na região, foi trabalhada com vistas a se tornar um dos espaços destinados ao conhecimento e divulgação desse passado. A Arqueologia e a 